\title{
Binding, Uptake and Toxicity of Alum Sludge
}


Digitized by the Internet Archive in 2015

https://archive.org/details/bindinguptaketox00albe 
BINDING, UPTAKE AND

TOXICITY OF ALUM SLUDGE

ALBERTA ENVIRONMENTAL CENTRE

FEBRUARY 5,1987 
This report may be cited as:

Alberta Environmental Centre. Binding, uptake and toxicity of alum sludge. Alberta Environmental Centre, Vegreville, AB. 118 p. 1986. AECV86-R10. 


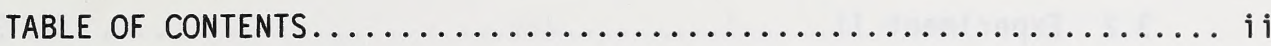

SUMMARY.................................. vi

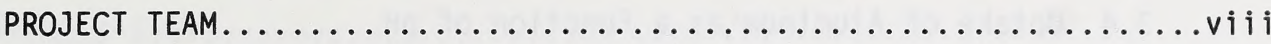

ACKNOWLEDGEMENTS $\ldots \ldots \ldots \ldots \ldots \ldots \ldots \ldots \ldots \ldots \ldots \ldots \ldots \ldots \ldots \ldots \ldots \ldots \ldots \ldots \ldots \ldots$

\section{PART I. BACKGROUND}

1. GENERAL INTRODUCTION.............................

2. WATER TREATMENT SYSTEMS $\ldots \ldots \ldots \ldots \ldots \ldots \ldots \ldots \ldots \ldots \ldots \ldots \ldots \ldots \ldots \ldots$

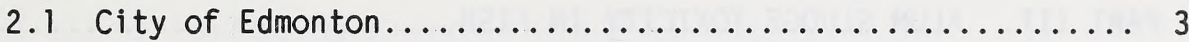

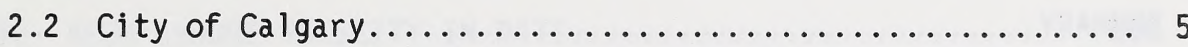

3. MATERIALS AND METHODS $\ldots \ldots \ldots \ldots \ldots \ldots \ldots \ldots \ldots \ldots \ldots \ldots \ldots \ldots \ldots \ldots \ldots$

3.1 Alum Sludge Collection...................... 7

3.2 Source of Fish and Their Maintenance.............. 10

3.3 Physico-Chemical Characterization of Sludge.......... 12

PART II. SPECIATION OF ALUMINUM AND UPTAKE BY FISH........... 14

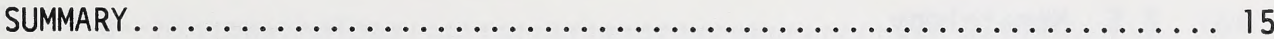

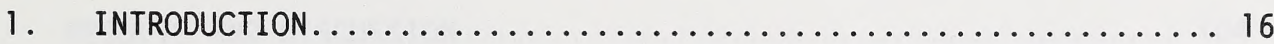

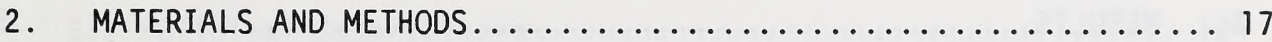

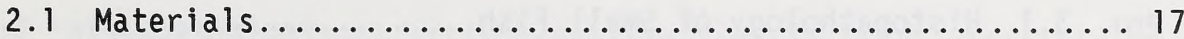

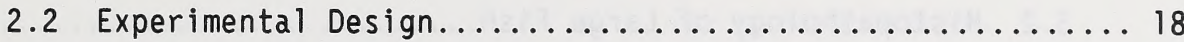

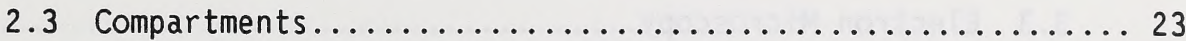

2.4 Speciation of Aluminum in Water................... 26

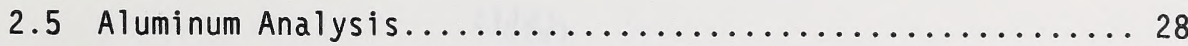


3. RESULTS AND DISCUSSION............................ 30

3.1 Experiment I................................ 30

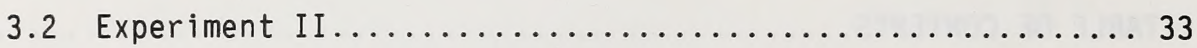

3.3 Speciation of Aluminum as a Function of $\mathrm{pH} \ldots \ldots \ldots \ldots 34$

3.4 Uptake of Aluminum as a Function of $\mathrm{pH} \ldots \ldots \ldots \ldots \ldots$

3.5 Effect of Competing Compartments on the Uptake of

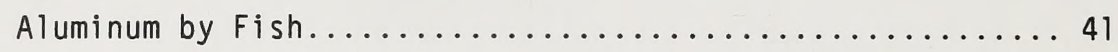

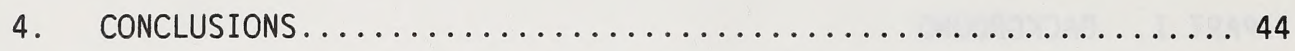

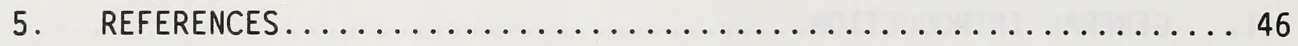

PART III. ALUM SLUDGE TOXICITY IN FISH.................. 47

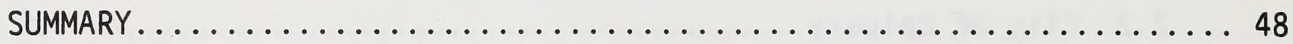

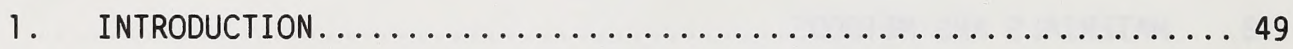

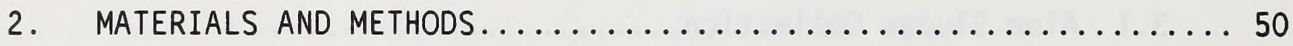

2.1 Acute Toxicity in Small Fish.................... 50

2.2 Subacute Toxicity in Large Fish.................. 52

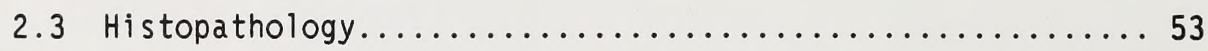

2.4 Electron Microscopy........................ 54

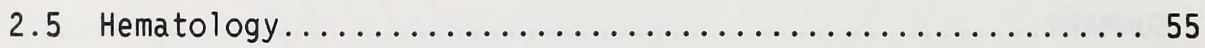

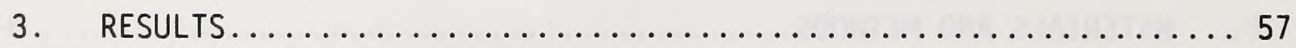

3.1 Histopathology of Small Fish...................... 57

3.2 Histopathology of Large Fish.................... 61

3.3 Electron Microscopy............................. 64 


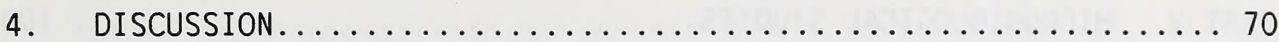

REFERENCE.............................. 70

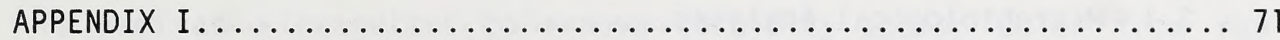

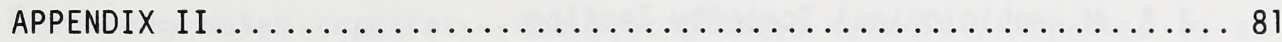

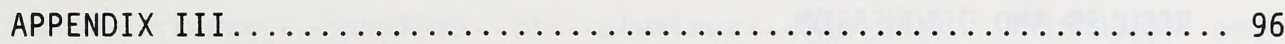

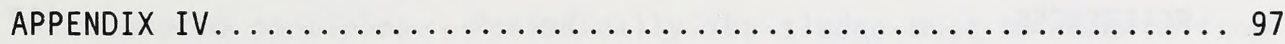

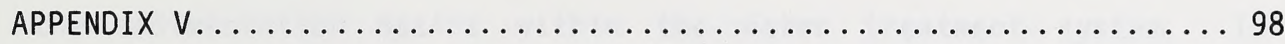

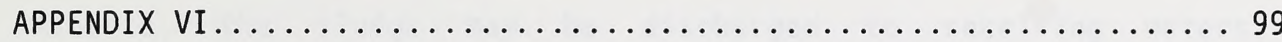

PART IV. ALUM SLUDGE TOXICITY IN RATS $\ldots \ldots \ldots \ldots \ldots \ldots \ldots \ldots \ldots$

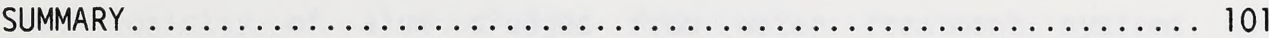

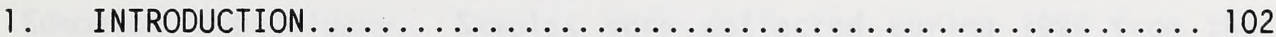

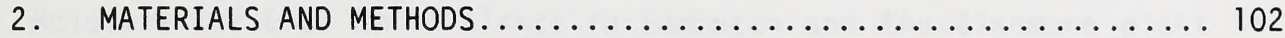

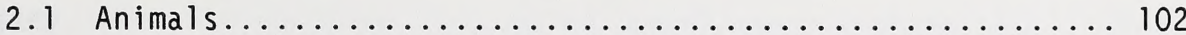

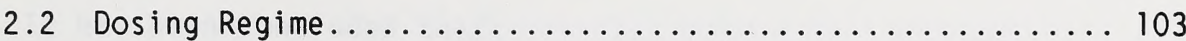

2.3 Clinical Observations......................... 103

2.4 Histopathology............................. 104

3. RESULTS AND DISCUSSION............................. 104

3.1 Clinical Observations......................... 104

3.2 Histopathology............................. 105 
PART $V$. MICROBIOLOGICAL STUDIES $\ldots \ldots \ldots \ldots \ldots \ldots \ldots \ldots \ldots \ldots \ldots \ldots \ldots \ldots \ldots \ldots \ldots$

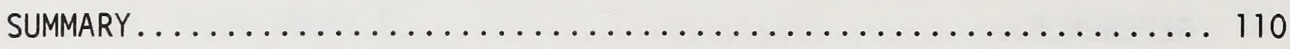

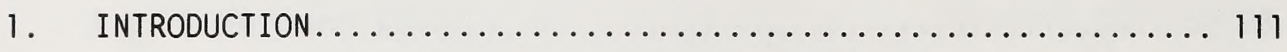

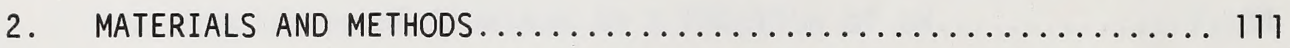

2.1 Microbiological Analyses....................... 111

2.2 Microbiological Toxicity Testing................. 113

3. RESULTS AND DISCUSSION............................ 114

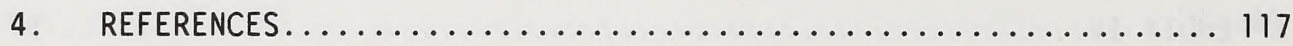




\section{SUMMARY}

Alum sludges are produced when alum $\left(\mathrm{Al}_{2}\left(\mathrm{SO}_{4}\right)_{3} 14 \mathrm{H}_{2} \mathrm{O}\right)$ is used as a coagulant to remove turbidity and/or color from raw drinking water supplies. The precipitated material, referred to as alum sludge, consists of aluminum hydroxide $\left(\mathrm{Al}(\mathrm{OH})_{3}\right)$ and flocculated particles. Periodically the sludge must be removed from the sedimentation basins within the water treatment system. In Alberta, the sludge may be discharged to receiving waters, transported to land-based disposal sites, or left on site.

The purpose of this study was to determine the binding, uptake and toxicity of alum sludges from water treatment systems in Edmonton and Calgary. Samples were collected during 1984 from the Rossdale and E.L. Smith plants in Edmonton and the Glenmore plant in Calgary.

It has been concluded that:

1) Aluminum was effectively bound to sludges within the $\mathrm{pH}$ range $4.5-10.0$, releasing only $<0.02 \%$ of its total aluminum content.

2) The bioconcentration factor of aluminum in rainbow trout exposed to alum sludge ranged from 0.4 to 12.3 . 
3) Alum sludge from all three treatment plants was considered acutely non-toxic to rainbow trout. No significant changes were observed in blood electrolytes, gases and $\mathrm{pH}$ in exposed fish. No significant tissue alterations were seen in gills, heart, oral cavity, eye, brain, liver, stomach, pyloric ceca, intestine, pancreas, spleen, kidneys, gonads, skin and muscle. There was no evidence of accumulation in gills.

4) Long Evans rats were dosed 1, 2 or 3 times with $3 \mathrm{ml}$ of undiluted sludge by gavage administration. During a 14 day observation period, there was no mortality or clinical signs of toxicity. All biochemical and hematological parameters were within established normal limits. Histopathological evaluation did not reveal any evidence of acute toxicity.

5) All sludges were found to be non-toxic using a microbial toxicity test system (Microtox). 

M. Albassam
M. Morwood-Clark
D. Bailey
A. Mutalib
R. Bhatnagar
L.E. Lillie
$K$. Blumhagen
J. Paran
F. Dieken
A. Qureshi
L. George
S. Ramamoorthy
C. Gulayets
D. Ringstad
M. Lefebvre
B. Verbeek
A. Lopez
K. Wilson
E. McGuinness
S. Yong
J.W. Moore*

*Project Manager

\section{ACKNOWLEDGEMENTS}

We would like to acknowledge the assistance of personnel from the City of Edmonton, particularly George Walker, and the City of Calgary for their assistance during this study. Dave Spink, Standards and Approvals Division, provided a considerable amount of assistance in all aspects of the study.

This work was initiated at the request of standards and Approvals Division, Alberta Environment. 

PART I

BACKGROUND

by

J.W. MOORE 



\section{GENERAL INTRODUCTION}

Aluminum, the second member of group IIIA of the periodic classification of elements, is a typical hard acid, forming strong electrovalent bonds with hard bases such as carbonate, sulphate, etc., through oxygen donor atoms. Aluminum salts of weak acids are readily hydrolysed and the extent of hydrolysis will depend on the base strength of the anion. Aluminum has a coordination number of six and forms hexa-aquo ion, $\mathrm{Al}\left(\mathrm{H}_{2} \mathrm{O}\right)_{6}^{3+}$ in water.

Aluminum is classified as a non-essential element and does not manifest any toxicity similar to heavy metals because of its lack of affinity for sulphur atoms. Aluminum in excess is known to bind phosphate ion and thus could interfere with transport processes.

Aluminum (Al) exists predominantly as $\mathrm{Al}(\mathrm{OH})_{\overline{4}}^{-}$at alkaline $\mathrm{pH}$ values and as trivalent ion, $\mathrm{Al}^{3+}$. In the $\mathrm{pH}$ range of environmental interest (4 to 8.5 ), several species including mononuclear hydroxy, polynuclear hydroxy and fluoride species have been reported. Colloidal and non-colloidal aluminum hydroxide species have also been identified. 
Alum sludges are produced when aluminum sulphate $\left[\mathrm{Al}_{2}(\mathrm{SO} 4)_{3} \cdot 14 \mathrm{H}_{2} \mathrm{O}\right]$ is used for coagulation and flocculation of raw water supplies to remove turbidity and/or colour. The floc particles are removed mainly during the sedimentation process in which the flocs slowly settle and form a sludge blanket. This blanket (hereinafter referred to as alum sludge) consists of aluminum hydroxide $\left[\mathrm{Al}(\mathrm{OH})_{3}\right]$ and other particles and flocculated materials. To maintain adequate efficiency of sedimentation basins, the alum sludge requires periodic or continuous removal and disposal.

The gelatinous sludge produced when aluminum sulphate is used as a coagulant in water treatment presents a difficult management and disposal problem. In Alberta, this sludge has commonly been discharged into nearby water courses on the assumption that it is a relatively innocuous waste.

Aluminum is one of the most abundant elements in nature. In a survey study in the United States it was found that concentrations of the aluminum in raw water could reach up to $5.35 \mathrm{mg} / \mathrm{L}$ and in drinking water up to $2.58 \mathrm{mg} / \mathrm{L}$, both are considered very high. Sources of aluminum in the water come from different venues. Recent studies have shown that acid rain has mobilized aluminum from soil to the aquatic environment (Robert et al., 1984, Helliwell et al., 1983). Apart from nature, significant quantities of aluminum come from the continuous discharge of alum sludges by water plants into the nearby streams and lakes. 
In human and other mammals, there is circumstantial evidence of an association between presence of aluminum compounds and development of neurological disorders and impaired bone mineralization (Geraldine et al., 1984). To our knowledge there is little information in the literature concerning the effect of alum sludges on fish and other aquatic animals. Helliwell et al. (1983) have concluded that dissolved aluminum in water ( $p H$ 5.8-6.2) is toxic to algae and perhaps to other aquatic organisms.

\section{WATER TREATMENT SYSTEMS}

\subsection{City of Edmonton}

Two water treatment facilities provide potable water to the City of Edmonton and to many of the communities in the greater Edmonton Region. These two facilities, the Rossdale and E.L. Smith water treatment plants, are collectively capable of treating an average $300 \mathrm{million}$ L/day of North Saskatchewan River water. The plants currently service a population in excess of 600,000 .

The basic treatment processes employed at these two plants are as follows:

i) pre-disinfection: chlorine dioxide is added to the water as a primary disinfectant and to aid in taste and odour control; 
ii) clarification:

iii) softening:

iv) secondary-disinfection: unfiltered water is disinfected

with chloramines; postdisinfection following filtration is also conducted on an as-needed basis;

iv) filtration:

the clarified and softened water is filtered through graded sand, constant rate, or dual media declining rate filters to remove any remaining particles.

Alum sludge is generated in the clarification process, and during the open water period, i.e., April through October, all the sludge generated is discharged to the North Saskatchewan River.

Approximately 2000 tonnes of aluminum sulphate are currently being used by the Rossdale and E.L. Smith plants 
during this April-October period. During the winter period when raw water particle counts are low, the clarification and softening processes are combined at the E.L. Smith plant and the resultant alum and lime sludge landfilled. Approximately 800 tonnes of alum are used at the Rossdale plant during the winter period and the resultant alum sludge is discharged continuously to the North Saskatchewan River. At both the Rossdale and E.L. Smith plants a number of clarification units are operated in parallel, and the nature of the alum sludge as well as the frequency of alum sludge discharges from each clarifier may vary. For this reason samples of alum sludge from each of the major clarification units at each of the plants were collected and tested.

\subsection{City of Calgary}

The City of Calgary has two water treatment facilities. The Glenmore Water Treatment Plant, located on the Elbow River adjacent to the Glenmore Reservoir, is capable of treating approximately 600 million L/day of water from the reservoir. The Bearspaw Water Treatment Plant, located on the Bow River just downstream of Bearspaw Reservoir, is capable of treating approximately 730 million L/day of water from the Bearspaw Dam. Collectively the two water treatment plants are capable of serving a population of about 800,000 .

The treatment processes employed at both the Glenmore and Bearspaw Water Treatment Plants are as follows: 
i) pre-chlorination: chlorine gas is added to disinfect the raw water;

ii) clarification: aluminum sulphate and polyelectrolytes are added to the raw water which then enters clarifiers where particles are removed by gravity sedimentation;

iii) filtration: the clarified water is filtered through either dual media or rapid sand filters;

iv) post-chlorination: additional chlorine gas is then added to maintain a chlorine residual throughout the distribution system.

At the Glenmore plant, the addition of aluminum sulphate as a coagulant is required only during periods when raw water turbidities are high. High turbidities are generally associated with either the spring thaw or heavy run-off periods and most frequently occur from April to July. The required aluminum sulphate dosages are relatively low. Approximately 300 tonnes of aluminum sulphate is currently being used per annum. The resultant alum sludge is allowed to accumulate in the clarifiers, and the sludge is removed once a year in the fall and discharged to the Elbow River. During the fall of 
1984 a sample of this sludge was collected for analysis and testing.

Alum sludge from the Bearspaw plant is no longer discharged to the Bow River. As part of a recent expansion to this plant, lagoon facilities were constructed to store alum sludge for subsequent landfilling. Alum sludges from the Bearspaw plant were therefore not collected as part of this study.

\section{MATERIALS AND METHODS}

3.1 Alum Sludge Collection

Alum sludges were collected from the water treatment plants on three different occasions.

First Sample Collection:

On September 21, 1984, four samples of alum sludge were collected from Rossdale plant \#1 and plant \#2, and E.L. Smith $C_{1}$ and $C_{2}$. Samples were collected in 60 litre polyethylene lined barrels. These barrels were prerinsed with sludge at each site before filling. Samples were transported to the laboratory and stored in a cold room at $5^{\circ} \mathrm{C}$. Dissolved oxygen, $\mathrm{pH}$, temperature and conductivity were measured every 3-4 days using Hydrolab 4041 meter. Average values of these readings are as follows: 


\begin{tabular}{lll}
$\frac{\text { Rossdale }}{\text { Plant \#1 Plant \#2 }}$ & \multicolumn{2}{l}{ E.L. Smith } \\
$C_{1}$ & $C_{2}$
\end{tabular}

$\begin{array}{llcll}\text { Temperature }\left({ }^{\circ} \mathrm{C}\right) & 7.9 & 8.35 & 9.28 & 8.08 \\ & 7.12 & 7.20 & 7.40 & 7.42 \\ \text { pH } & & 1.83 & 6.86 & 7.23\end{array}$

(DO) $(\mathrm{mg} / \mathrm{L})$

$\begin{array}{lllll}\text { Conductivity } & 150.75 & 191.75 & 132.33 & 141.66\end{array}$

(Cond.) $(\mu \mathrm{s} / \mathrm{cm})$

Second Sample Collection:

On October 24,1984 , a second collection trip was made to Rossdale and E.L. Smith water treatment plants. At Rossdale plant \#1 a total of 227 litres of alum sludge was collected in two new polyethylene lined barrels. The barrels were rinsed with sludge prior to sample collection. Since the plant's systems had been recently cleaned, the sludge differed greatly in appearance from the September collection. This sample was for acute and subacute studies.

At the same time of collection, a sterile 1 litre bottle was used to collect a sample for microbiological analysis. No sample was collected from Rossdale Plant \#2 due to lack of access to the site. On this same day two samples of 227 litres each were collected from E. L. Smith Plant $C_{1}$ and $C_{2}$ in four new polyethylene lined barrels which were prerinsed with the appropriate sludge. 
At each site a sterile 1 litre bottle was used for collection of sludge for bacterial counts. The samples were transported back to the laboratory and stored in a cold room at $5^{\circ} \mathrm{C}$ until use. These samples were used for the subacute studies.

Parameters of dissolved oxygen, $\mathrm{pH}$, temperature and conductivity were measured on October 29, 1984 using a Hydrolab 4041 meter as follows:

\section{Rossdale Plant \#1}

$C_{1}$

\section{E.L. Smith}

$C_{1}$

$\mathrm{C}_{2}$

$\begin{array}{lrrr}\text { Temperature } & 5.9 & 5.7 & 5.9 \\ \mathrm{pH} & 6.9 & 7.1 & 7.3 \\ \text { DO } & 10.9 & 9.6 & 9.4 \\ \text { Conductivity } & 346.0 & 360.0 & 393.0\end{array}$

Third Sample Collection

On October 5, 1984, a total of 227 litres of alum sludge was received from the Glenmore water treatment plant in two polyethylene lined barrels. The samples were collected on October 2-3, 1984, from 0900 - $1000 \mathrm{~h}$ as a grab sample. The samples were stored at $6^{\circ} \mathrm{C}$ in a cold room until use. This sample was used for acute and subacute studies.

Dissolved oxygen, $\mathrm{pH}$, temperature, and conductivity were measured with Hydrolab 4041 metre. Average values are as follows: 


$\begin{array}{ll}\text { Temperature } & 5.90 \\ \text { pH } & 6.76 \\ \text { DO } & 2.12\end{array}$

Conductivity $\quad 390.16$

An aliquot of each of the sludge samples was filtered using a buchner funnel, Whatman No. 40 ashless filter paper and a vacuum pump to determine relative amounts of solid material in each sample collected. The barrels were well mixed prior to sample collection, and it was determined that a constant weight reading occurred after 5 minutes. The amount of solids (expressed as wet weight) are as follows:

Rossdale plant \#1 collected 21/09/84 $27.41 \mathrm{~g}$ solids/L

Rossdale plant \#1 collected 22/10/84 $6.26 \mathrm{~g} \mathrm{solids/L}$

Rossdale plant \#2 collected 21/09/84 $275.7 \mathrm{~g}$ solids/L

E.L.Smith plant $C_{1}$ collected $21 / 09 / 84 \quad 36.92 \mathrm{~g}$ solids/L

E.L.Smith plant C, collected 24/10/84 $97.90 \mathrm{~g}$ solids/L

E.L.Smith plant $C_{2}$ collected $21 / 09 / 84 \quad 98.36 \mathrm{~g}$ solids/L

E.L.Smith plant $C_{2}$ collected $24 / 10 / 84 \quad 19.98 \mathrm{~g}$ solids/L

Glenmore plant collected 2-3/10/84 $62.25 \mathrm{~g} \mathrm{solids/L}$

\subsection{Source of Fish and Their Maintenance}

Rainbow trout were obtained as eggs from Mt. Lassen Trout Farm (California), and as fry from the Environmental Protection Service (obtained from Sun Valley Hatchery in British 
Columbia). The eggs were reared in the laboratories of the Aquatic Biology Group. Table 1 gives the chemistry of water used in egg rearing. Table 2 gives the chemistry of water after the fry were transferred from the egg incubators. Fry obtained from the Environmental Protection Service were allowed to acclimate at least 2 weeks prior to experimentation. Fish measured $3.93 \pm 1.17( \pm \mathrm{SD}) \mathrm{cm}$ in length and $0.86 \pm 0.6 \mathrm{~g}$ wet weight at the time of experimentation.

Table 1. Physico-chemical characteristics of water used to rear rainbow trout eggs. Concentration expressed as means and ranges ( $\left.\mathrm{mg} \mathrm{L}^{-1}\right)$.

\begin{tabular}{lccrr}
\hline & DO & pH & Temp. & Cond. \\
\hline $\begin{array}{l}\text { Mt. Lassen eggs } \\
\text { (Incubator) }\end{array}$ & 9.4 & 7.86 & 14.1 & 198.4 \\
$\begin{array}{l}\text { Mt. Lassen eggs } \\
\text { (cold room) }\end{array}$ & $\begin{array}{l}10.3 \\
(9.2-11.4)\end{array}$ & $\begin{array}{c}7.78 \\
(7.61-8.03)\end{array}$ & $(7.0-11.5)$ & $(160-205)$ \\
\hline
\end{tabular}

Table 2. Physico-chemical* conditions of water used to maintain rainbow trout fry. Concentration expressed as means and ranges ( $m g L^{-1}$ ).

$\begin{array}{ll}\text { D.0. } & 9.6(8.1-11.7) \\ \text { pH } & 7.48(7.29-7.71) \\ \text { Temp }{ }^{\circ} \mathrm{C} & 14.0(13.0-16.0) \\ \text { Cond. } & 174.0(155-199)\end{array}$

*These parameters were measured at the start of the test and every 24 hours thereafter. 
Large rainbow trout measuring $33.4 \pm 3.7 \mathrm{~cm}$ in length and $453.6 \pm 106.5 \mathrm{~g}$ wet weight were used for the subacute toxicity studies. These fish were obtained from Trout Springs Ltd. in Calgary. They were maintained in the laboratories of the Aquatic Biology Group for 3 weeks prior to exposure. Table 3 gives the physico-chemical conditions of the water in which they were maintained.

Table 3. Physico-chemical* conditions of water used to maintain the large rainbow trout. Concentrations expressed as means and ranges ( $\mathrm{mg} \mathrm{L}^{-1}$ ).

\begin{tabular}{lll}
\hline $\mathrm{D} .0$. & 9.03 & $(7.30-10.60)$ \\
pH & 7.38 & $(6.93-7.7))$ \\
Temp ${ }^{\circ} \mathrm{C}$ & $12.8(11.0-14.5)$ \\
Cond. & $198.0(150-250)$ \\
& &
\end{tabular}

*These parameters were measured at the start of the test and every 24 hours thereafter.

\subsection{Physico-chemical characterization of sludge}

Physico-chemical analysis was conducted by the Chemistry Wing (Alberta Environmental Centre) on samples collected from the Rossdale and E.L. Smith plants (Table 4). The samples were variable in composition, depending on when the clarifiers were last cleared of precipitated material. Thus the non-filterable residue (NFR) varied from 152 to $49600 \mathrm{mg} / \mathrm{L}$ and the Biological Oxygen Demand (BOD) from 1.7 to $16.3 \mathrm{mg} / \mathrm{L}$. Although the concentration of most metals was generally low, aluminum was recorded at $25.1 \mathrm{mg} / \mathrm{L}$ in one sample. 
Table 4. Physico-chemical analysis of sludge samples.

Parameter

Rossdale 1 E.L. Smith 1 E.L. Smith 2

\begin{tabular}{|c|c|c|c|}
\hline Conductivity $(\mu \mathrm{S} / \mathrm{cm})$ & 376 & 444 & 467 \\
\hline Magnesium (mg/L) & 15 & 43 & 42 \\
\hline Calcium & 82 & 240 & 244 \\
\hline Cadmium & 0.002 & 0.013 & 0.009 \\
\hline Copper & 0.032 & 0.169 & 0.124 \\
\hline Nickel & 0.017 & 0.135 & 0.103 \\
\hline Cobalt & 0.015 & 0.067 & 0.049 \\
\hline Zinc & 0.060 & 0.585 & 0.762 \\
\hline Aluminum & 25.060 & -- & -- \\
\hline Beryllium & $<0.0001$ & 0.004 & 0.003 \\
\hline Manganese & 0.156 & 2.230 & 1.700 \\
\hline Vanadium & 0.012 & 0.192 & 0.127 \\
\hline Molybdenum & 0.021 & 1.030 & 0.627 \\
\hline Lead & 0.035 & 0.028 & 0.030 \\
\hline Arsenic & 0.0033 & 0.0869 & 0.1000 \\
\hline Selenium & 0.0004 & 0.0021 & 0.0018 \\
\hline BOD (Biological Oxygen Demand) & 1.7 & 16.3 & 15.3 \\
\hline COD (Chemical Oxygen Demand) & 85.1 & 1505.7 & 1044.0 \\
\hline NFR (Non-filterable Residue) & 152 & 4960 & 3409 \\
\hline FR (Filterable Residue) & 240 & 290 & 300 \\
\hline TR (Total Residue) & 392 & 5250 & 3709 \\
\hline TP (Total Phosphorus) & 0.245 & 4.750 & 3.800 \\
\hline TKN (Total Kjeldahl Nitrogen) & 4.000 & 39.500 & 29.500 \\
\hline TN (Total Nitrogen) & 1.00 & 105.00 & 50.00 \\
\hline Ammonia & 2.800 & 1.390 & 0.990 \\
\hline Nitrite & $<0.001$ & 0.002 & .003 \\
\hline DOC (Dissolved Organic Carbon) & 2.0 & 3.2 & 3.4 \\
\hline DIC (Dissolved Inorganic Carbon) & 30.4 & 37.8 & 40.6 \\
\hline TC (Total Carbon) & 46.40 & 1054.00 & 642.00 \\
\hline
\end{tabular}

-- dash, no data. 

(14)

\section{PART II \\ SPECIATION OF ALUMINUM AND UPTAKE BY FISH}

by

S. Ramamoorthy and Lee George 



\section{SUMMARY}

1. These studies show that aluminum (A1) is effectively bound in the sludge at all pH values from 4.5 to 10.0 , the sludge releasing less than $0.02 \%$ of its total Al content.

2. Relatively higher levels of $A l$ are released at extreme $\mathrm{pH}$ values of 4.5 and 10.0 .

3. Environmentally significant compartments such as suspended solids, cationic and anionic exchange surfaces compete effectively with fish in the uptake of $\mathrm{Al}$.

4. The uptake of $\mathrm{Al}$ by fish reaches a "steady state" in $48 \mathrm{~h}$ and the maximum amount bioconcentrated in natural $\mathrm{pH}$ values $(7.6)$ is $\sim 9$ $\mathrm{mg} / \mathrm{Kg}$ wet weight regardless of the source of $\mathrm{Al}$.

5. Speciation studies showed that $A l$ exists as $\mathrm{Al}^{3+}$ ions in acidic $\mathrm{pH}$, as complexed (Filterable-Non-Exchangeable)-Al species in neutral $\mathrm{pH}$ and as $\mathrm{Al}(\mathrm{OH})_{4}^{-}$(Filterable-Anion- Exchangeable-Al) species in alkaline $\mathrm{pH}$.

6. The speciation data could be used by waterworks engineers and aquatic toxicologists. It may be desirable to discharge the alum sludge during periods of high suspended solids load or by mixing it with naturally occurring polyelectrolytes of plant origin prior to discharge to minimize the exposure concentration of $A l$ to fish in natural waters. The aquatic toxicologist can interpret the effect data better by correlating to the correct species of $A 1$ present under the conditions of the experiment. 


\subsection{INTRODUCTION}

This study was conducted in two parts: (i) Experiment-I -- Uptake of $\mathrm{Al}$ by fish from different Al-containing compounds including alum sludge in the presence of competing compartments and (ii) Experiment-II -- Effect of $\mathrm{pH}$ from 4.5 to 10.0 on the uptake of $A 1$ by fish in the presence of competing compartments similar to Experiment-I. Speciation of Al was studied at the chosen $\mathrm{pH}$ values in Experiment-II. In this study, a multi-compartmental system was used to determine the intercompartmental competition to partition the available Al. 


\subsection{MATERIALS AND METHODS}

\subsection{Materials:}

A simple laboratory simulation of an aquatic ecosystem was used to study the competitive interactions among compartments on the uptake of Al by fish (Figure 1). The compartments chosen were source of Al, North Saskatchewan River (NSR) water, suspended solids, cation-exchange resin (CER), anion-exchange resin (AER) (both resins to represent the naturally occurring polyelectrolyte materials of plant origin whose ion-exchange capacity and strength of bonding vary from weak to strong depending on the composition, chain length, and functional group on the polyelectrolyte backbone), and biota as represented by fish (rainbow trout). River water was contained in a $5.5 \mathrm{~L}$ borosilicate glass tank and the other compartments were separated by enclosing them in dialysis sacs. The sacs were suspended in the continuously stirred water in the dialysis tank (Figure 1). The dialysis tanks were kept in a temperature-controlled water bath at $15 \pm 0.1^{\circ} \mathrm{C}$. Illumination was provided by cool-white fluorescent light, and incandescent bulbs simulated a 15-min dawn or dusk light intensity change. A constant 12-h light: 12h-dark photoperiod was controlled by an automatic timer. 


\subsection{Experimental Design:}

2.2.1 Experiment-I was set up in five dialysis tanks to follow the Al flux from the source to the compartments at chosen time intervals (Figure 1). The design of five tanks and sampling schedule is given in Table 1.

Table 1. Aluminum Uptake by Fish in the Presence of Competing Compartments

\begin{tabular}{|c|c|c|c|c|c|}
\hline $\begin{array}{l}\text { Time / } \\
\text { Tank }\end{array}$ & $\begin{array}{c}1 \\
\text { control }\end{array}$ & $\begin{array}{l}2 \\
\text { Aluminum } \\
\text { sulphate }\end{array}$ & $\begin{array}{c}3 \\
\text { Alum }\end{array}$ & $\begin{array}{c}4 \\
\text { Alum } \\
\text { Sludge }\end{array}$ & $\stackrel{5}{\text { Alum Sludge }_{+}}$ \\
\hline
\end{tabular}

$6 \mathrm{~h}$

$12 \mathrm{~h}$

$24 \mathrm{~h}$

$48 \mathrm{~h}$

$96 \mathrm{~h}$

$144 \mathrm{~h}$

13 days
Compartments in each tank

Cation exchange resin

Suspended solids

Fish

Filtered river water

appropriate aluminum compound/tank

$16 /$ tank
Anion exchange resin

$2 \mathrm{~g} \mathrm{DW}^{+} / \mathrm{sac}$ (8 sacs/tank)

$1 \mathrm{~g} \mathrm{DW} / \mathrm{sac}$ (8 sacs/tank)

$1 \mathrm{~g} \mathrm{DW} / \mathrm{sac}$ (8 sacs/tank)

5 litres/tank

${ }^{*} D O M=$ Dissolved organic matter at $30 \mathrm{ppm}$ concentration in water $\dagger \quad=$ Dry weight

At each specified sampling time,

(i) one sac each of cationic resin, anionic resin and suspended solids

(ii) two fish and

(iii)one water sample $(110 \mathrm{ml})$ were removed from each tank for $A l$ analysis. The source for aluminum in 


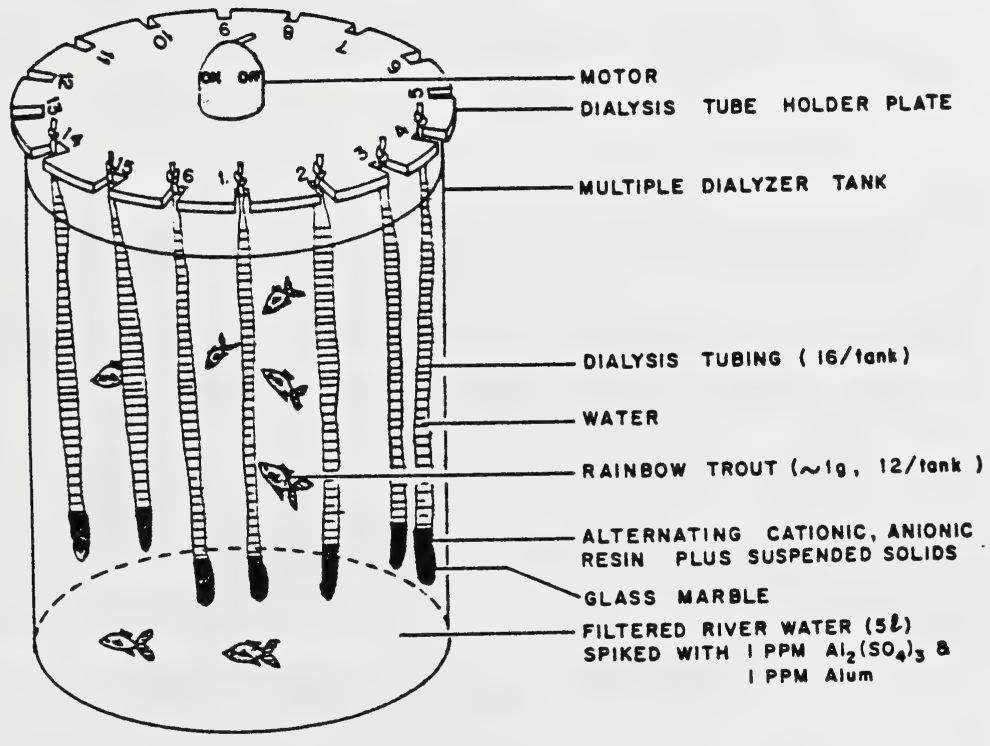

Figure 1. 
the control tank was the unspiked NSR water and in tanks \#2 and \#3 was NSR water spiked with $1 \mathrm{mg} / \mathrm{L}$ of aluminum sulphate and $1 \mathrm{mg} / \mathrm{L}$ of anhydrous alum (formula weight 258.4) respectively. The fourth and fifth tanks contained alum sludge at the bottom of the tank covered with a nylon mesh as the source for Al (Figure 2). The NSR water in tank \#5 was spiked with $30 \mathrm{mg} / \mathrm{L}$ of dissolved organic matter.

\subsubsection{Experiment II}

Experiment-II was also set up in five dialysis tanks (Figure 3) to study (i) effect of varying the $\mathrm{pH}$ on the release of $A l$ from alum sludge, (ii) Al speciation in the water column at respective $\mathrm{pH}$ values and ( $\mathrm{i} i \mathrm{i}$ ) partitioning of $\mathrm{Al}$ among compartments and determine its bioconcentration in fish. Information on the chosen $\mathrm{pH}$ value for each tank and sampling times is given in Table 2. The sampling schedule except for water was similar to Experiment-I (Table 1).

In a typical experiment, the dialysis sacs containing the chosen compartment(s) (suspended solids, or ion-exchange resin) were suspended in about $5 \mathrm{~L}$ of NSR water. Analytically pure aluminum sulphate and alum were used for spiking NSR water for the source of Al. The water was stirred by the mechanical rotation of the 
dialysis sacs in the dialyzer tanks (Pope Scientific Co., U.S.A.). Dialysis sacs, whole fish, and samples of water were removed at specified times and analyzed for total Al concentration. Control values were obtained for background $A l$ levels in all compartments and in the dialysis tubing. Wherever control levels were significant, necessary corrections were made in the calculations. Fish were not fed during the course of the experiments.

Table 2. Aluminum Speciation and Uptake at Environmentally Significant pH's.

Time/Tank

$\begin{array}{llllll}1 & 2 & 3 & 4 & 5 & \\ 4.5 & 6.0 & 7.65 & 9.0 & 10.0 & \mathrm{pH}\end{array}$

3h Compartments in each tank

$6 \mathrm{~h} \quad$ Cation exchange resin --- $2 \mathrm{~g} \mathrm{DW} / \mathrm{sac}$ ( $6 \mathrm{sacs} / \mathrm{tank}$ )

12h Anion exchange resin-.-- $1 \mathrm{~g} \mathrm{DW} / \mathrm{sac}$ ( $6 \mathrm{sacs} /$ tank)

$24 \mathrm{~h} \quad$ Suspended solids -.-- $1 \mathrm{~g} \mathrm{DW} / \mathrm{sac}$ ( $6 \mathrm{sacs} / \mathrm{tank}$ )

48h Fish -..- 12/tank

96h Filtered river water --.- 5 litres/tank

Alum sludge at bottom --- $125 \mathrm{~g} /$ tank

At each specified sampling time,

(i) one sac each of cationic resin, anionic resin and suspended solids

(ii) two fish and

(iii)two water samples ( $110 \mathrm{ml}$ each) were removed from each tank for Al analysis. 


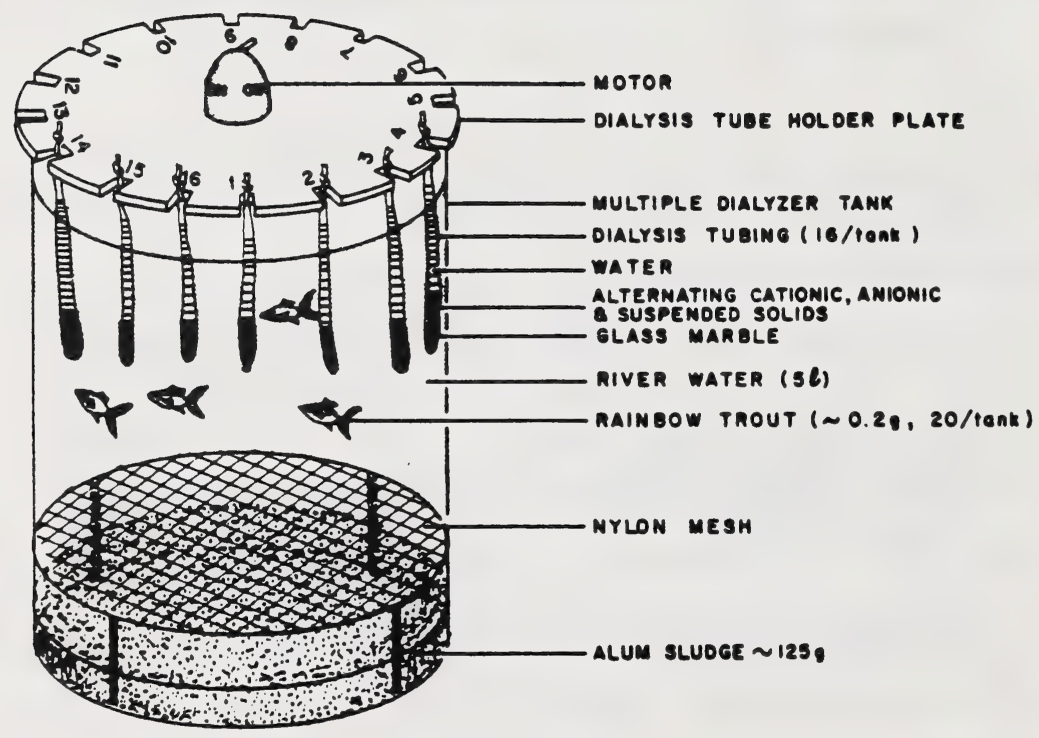

Figure 2. 


\subsection{COMPARTMENTS}

\subsubsection{BIOTA}

The first batch of fish used were 12-week-old rainbow trout hatched from eggs in our laboratory (average wet weight, 0.54 g). The second batch of fish were about 20-week-old (average wet weight, $1.20 \mathrm{~g})$. The resultant loading densities were approximately $1.7 \mathrm{~g} / \mathrm{L}$ (experiment I) and $2.9 \mathrm{~g} / \mathrm{L}$ (experiment II). The fish did not appear to be unduly stressed by crowding at these densities.

\subsubsection{SUSPENDED SOLIDS}

Pulverized montmorillonite clay was used as suspended solid, since geological weathering of soil clays and their erosion, particularly during spring run-off contribute to much of the suspended solid load in rivers. The cation exchange capacity of some pertinent clay minerals is listed below (Ramamoorthy and Leppard, 1977):

\begin{tabular}{llclll}
\hline $\begin{array}{l}\text { Type of } \\
\text { Clay }\end{array}$ & Occurrence & $\begin{array}{c}\text { CEC } \\
\text { (meq/100 g) }\end{array}$ & $\begin{array}{l}\text { Location of } \\
\text { CEC }\end{array}$ & $\begin{array}{l}\text { Surface } \\
\text { Area } \\
\left(\mathrm{m}^{2} / \mathrm{g}\right)\end{array}$ & $\begin{array}{l}\text { Area } \\
\left(\mathrm{nm}^{2} /\right. \\
\text { exch } \\
\text { site })\end{array}$ \\
\hline Kaolinite & $\begin{array}{l}\text { podzols and } \\
\text { tropical soils }\end{array}$ & $3-15$ & External & 16.6 & 0.387 \\
Illite & Many soil types & $10-40$ & External & 92.0 & 0.566 \\
$\begin{array}{l}\text { Montmor- } \\
\text { illonite }\end{array}$ & Many soil types & $95-150$ & $\begin{array}{l}20 \% \text { external } \\
\text { and 80\% in } \\
\text { interlamellar } \\
\text { spaces }\end{array}$ & 750.0 & 1.545 \\
\hline
\end{tabular}




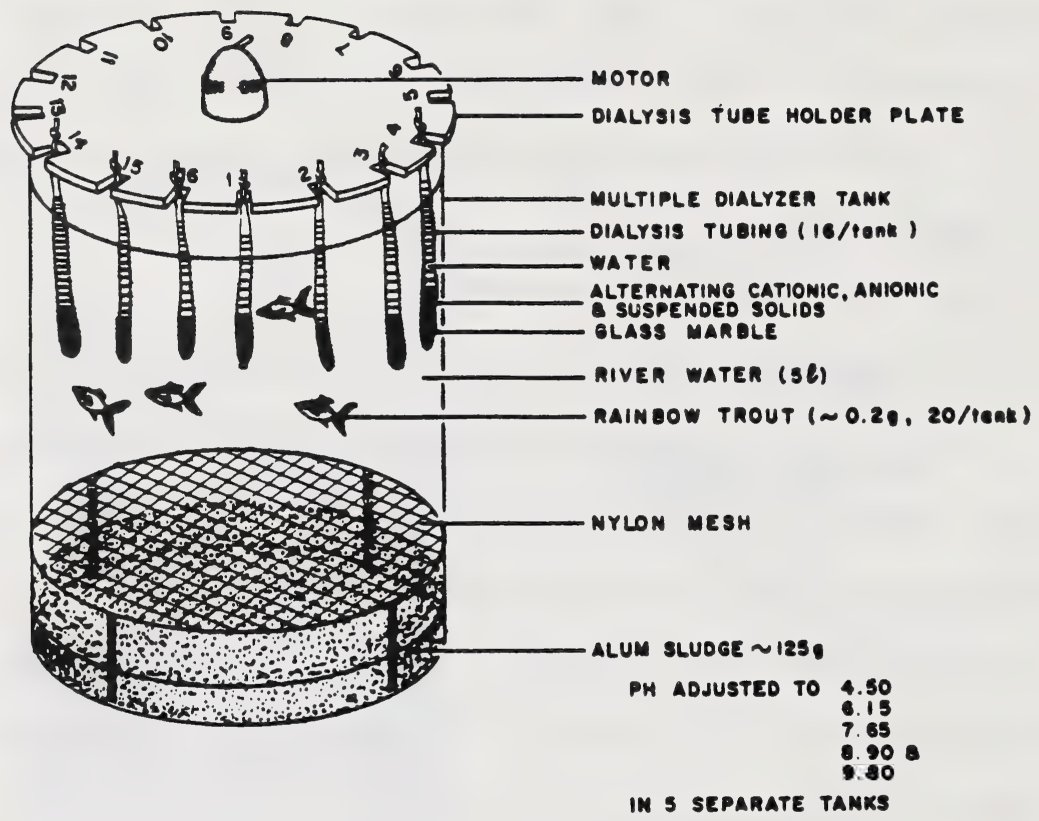

Figure 3. 
The clay minerals suspended in water will provide a larger surface area per gram than the sediment for interaction with Al species and thus meaningfully represent the suspended solids in rivers. The suspended solids were placed in dialysis sacs with 5 $\mathrm{ml}$ of deionized water. The average pore diameter of the dialysis sac membrane is $4.8 \mathrm{~nm}$ and the molecular weight cut-off is 12,000. The dialysis sacs are highly permeable to metals and their complexes (with organic ligands and fulvic acid) below molecular weight 12,000 .

\subsubsection{ION - EXCHANGE RESINS}

Cationic and anionic resins (Amberlite, IRC-50 (H) and IR-45 $(\mathrm{OH})$, respectively) were swelled in water prior to placing in dialysis sacs ( $2 \mathrm{~g}$ for cationic resin and $\mathrm{l} g$ for anionic resin plus $5 \mathrm{ml}$ of deionized water in each sac).

\subsubsection{RIVER WATER}

Filtered NSR water $(\mathrm{pH}=7.65$ and conductivity $=375 \mu \mathrm{S} / \mathrm{cm}$ ) was used in both experiments. Five litres of this water were added to each tank. The trace metal concentrations (mg/L) in NSR water were as follows: $\mathrm{Hg}(<0.001), \mathrm{Cu}(<0.001), \mathrm{Cd}(<0.001), \mathrm{Zn}$ $(=0.010), \mathrm{Co}(<0.0001), \mathrm{Pb}(0.005), \mathrm{Ni} \quad(=0.010), \mathrm{Mn} \quad(<0.008)$ and Al $(=0.040)$. 


\subsubsection{ORGANIC MATTER}

Approximately $150 \mathrm{~g}$ of black soil was collected from the agricultural lots adjacent to the Alberta Environmental Centre, Vegreville, Alberta. The soil characteristics are as follows: type $=$ black solodized solonetz soil of $\mathrm{A}$ horizon; composition = sand $(50 \%)$, silt $(32 \%)$, and clay $(18 \%)$; percent organic matter = $6.6 \%$; minerals $(\mathrm{mg} / \mathrm{Kg})=\mathrm{N}(27), \mathrm{P}(8), \mathrm{K}(128)$, and $\mathrm{Na}(250) ; \mathrm{pH}$ $=7.1$ and conductivity $=2 \mathrm{mS}$. The soil was extracted with $0.5 \mathrm{M}$ $\mathrm{NaOH}$ under nitrogen for $18 \mathrm{~h}$. The extract was then separated from the residue, and the humic and fulvic acids were isolated by the method described by Schnitzer and Skinner (1968). The ion-exchange treatment of the extract removes all trace metal present. The freeze-dried fulvic and humic acids were added to the water column as a source of dissolved organic matter.

\subsection{SPECIATION OF ALUMINUM IN WATER}

About $110 \mathrm{ml}$ of water was collected twice from each tank at the specified sampling time. One was for total Al analysis and the other for Al speciation as described below:

1. The water sample was centrifuged with a table centrifuge to remove the particulate matter, if any. The supernatant water was taken for further treatment and the residue for $A 1$ analysis. The residue was termed sample ' $A$ '. 
2. $100 \mathrm{ml}$ of nanopure water (NPW) was eluted through the cation exchange resin (CER) column and collected in a polypropylene (PP) bottle -- sample 'B' (blank).

3. The water sample free from particulate matter was eluted through the CER column and collected in a conical flask. This eluate was free from cation-exchangeable-Al.

4. The CER column was eluted with $0.1 \mathrm{M}$ Nitric acid solution thrice with $20 \mathrm{ml}$ each time, followed by two rinsings with 20 ml NPW and collected in a PP bottle -- samples ' $C$ '. This was the cationic-exchangeable-Al fraction.

5. A NPW blank (similar to step \#2) was obtained for anionic-exchange resin (AER) column and collected in a PP bottle -- sample 'D'.

6. The eluate from step \#3 was eluted through the AER column and collected with the two NPW rinses in a PP bottle -- sample 'E'. This was the 'Residual-Al fraction', free from both cationic-and anionic-Al.

7. The AER column was eluted with $0.1 \mathrm{M} \mathrm{NaOH}$ solution similar to step \#4 and collected in a PP bottle -- sample ' $F$ '. This was the anionic-exchangeable-Al fraction.

8. Thus there were a total of 7 samples of water at each sampling time, 6 samples for speciation and 1 for total Al analysis. 


\subsection{ALUMINUM ANALYSIS}

\subsubsection{Suspended solids:}

$0.5 \mathrm{~g}$ of the sample was weighed into a Teflon beaker, a mixture of $10 \mathrm{ml}$ concentrated (conc.) hydrofluoric acid $+3 \mathrm{ml}$ conc. Perchloric acid $+3 \mathrm{ml}$ of nitric acid was added and heated to dryness. Another $2 \mathrm{ml}$ of conc. perchloric acid was added and heated to dryness again. The residue was dissolved in $3 \mathrm{ml}$ of nitric acid and 10-15 $\mathrm{ml}$ of deionized water was added and then heated on a hot plate for about 5-10 min for complete dissolution. The solution was cooled and made up to a known volume and aspirated into nitrous oxide-acetylene flame of an atomic absorption spectrophotometer (AAS) for Al determination.

\subsubsection{Resins:}

$0.5 \mathrm{~g}$ of the resin sample was weighed into a beaker, $5 \mathrm{ml}$ of conc. nitric acid was added and heated to about $0.5 \mathrm{ml}$ of residual volume. One $\mathrm{ml}$ of nitric acid and $15 \mathrm{ml}$ of water was added and heated on a hot plate for 5-10 min. The solution was cooled and made up to a known volume and analyzed for Al. Cationic resin sample was analyzed by graphite tube furnace (Varian GTA 95) on Varian 475 AAS (ASTM, 1980). The anionic sample was analyzed by solvent extraction method using Varian AAS (EPA, 1979). 


\subsubsection{FISH}

The whole fish was weighed into a beaker, $10 \mathrm{ml}$ of conc. nitric acid was added and heated gently until the fish decomposed. Heating was continued until the sample was dry and then ashed at $400^{\circ} \mathrm{C}$ in a muffle furnace to remove the organic matter. The solution was cooled, dissolved in $2 \mathrm{ml}$ of conc. nitric acid, made up to a known volume and analyzed by the solvent extraction method using an AAS.

\subsubsection{WATER}

$100 \mathrm{ml}$ of the water sample was taken in a $200 \mathrm{ml}$ volumetric flask, $\mathrm{pH}$ was adjusted to $8.0 \pm 0.5$ with conc. ammonium hydroxide. Two $\mathrm{ml}$ of $2 \%$-hydroxyquinoline - acetic acid mixture was added and allowed to stand for $10 \mathrm{~min}$. Ten $\mathrm{ml}$ of ammonium acetate - ammonium hydroxide buffer was added followed by quick addition of $10 \mathrm{ml}$ of methyl isobutyl ketone (MIBK). The solution was shaken vigorously for $15 \mathrm{sec}$, the organic layer was floated to the neck of the flask and aspirated into the nitrous oxideacetylene flame of an AAS (EPA, 1979).

\subsubsection{CONDITIONS FOR GRAPHITE TUBE FURNACE METHOD:}

The sample was charred at $1400^{\circ} \mathrm{C}$ for $3 \mathrm{sec}$ and atomized at $2500^{\circ} \mathrm{C}$. 


\subsubsection{DETECTION LIMIT:}

For solvent extraction method $=0.005 \mu \mathrm{g} / \mathrm{g}$ or $\mu \mathrm{g} / \mathrm{ml}$

For graphite furnace method $=0.001 \mu \mathrm{g} / \mathrm{g}$ or $\mu \mathrm{g} / \mathrm{ml}$

\subsubsection{RECOVERY:}

For solvent extraction method $=95 \%$

For graphite furnace method $=95 \%$ with background adjusted and matrix matched

\subsection{RESULTS AND DISCUSSION}

\subsection{Experiment - I}

The concentration of aluminum (Al) in the water column was about $30 \%$ of the amount spiked $(1.0 \mathrm{mg} / \mathrm{L})$ in tanks \#2 and 3 with aluminum sulphate and alum respectively, whereas the amount of $A 1$ leaching from the alum sludge (tank \#4) was about $0.001 \%$ of its total aluminum content $(78,187 \mathrm{mg}$ of $\mathrm{Al} / \mathrm{Kg}$ of sludge). The presence of organic matter at a concentration of $30 \mathrm{mg} / \mathrm{L}$ resulted in increased leaching of Al from the sludge (tank \#5). The aqueous concentration of $A l$ in tanks \#4 and 5 was slightly lower $(0.202$ and $0.264 \mathrm{mg} / \mathrm{L}$ respectively) than in tanks \#2 and $3(0.290$ and $0.319 \mathrm{mg} / \mathrm{L}$ respectively) (Table 3 ).

The amount of $A l$ accumulated by fish seems to reach a "steady state" at $48 \mathrm{~h}$ and further exposure with time did not increase the 
Al concentration in fish, including the positive control tank. The amount of $\mathrm{Al}$ bioconcentrated by fish in the presence of competing compartments such as suspended solids, resins (CER and AER) was more or less the same ( $9 \mathrm{mg} / \mathrm{kg}$ wet weight) from unspiked river water and from river water spiked with synthetic Al compounds (Table 3) whereas, with alum sludge as the source for Al (tank \#4) the amount bioconcentrated by fish was about half of that taken up in tanks \#l to 3. The presence of organic matter in the water column containing alum sludge (tank \#5) increased the Al uptake by fish to a level on par with tanks \#1 to 3 (Table 3 ). The average bioconcentration factor, $B C F \quad(B C F=$ amount of $A l$ in fish, $\mathrm{mg} / \mathrm{kg}$ wet wt./concentration of $A l$ in water column, $\mathrm{mg} / \mathrm{L}$ ) was calculated to be 30 (excluding tank \#1). The BCF for fish exposed to alum sludge was 23 . The relatively higher BCF (200) for control NSR water shows that fish bioconcentrate Al effectively from low concentrations ( 7 times lower than the concentrations in spiked solutions) to accumulate the maximum loading level for $A l$ in fish tissue ( $9 \mathrm{mg} / \mathrm{kg}$ wet wt.).

Competition of abiotic compartments in the system for $A l$ is shown quantitatively for CER. The average partition coefficient between CER and water was 28 . The closeness of BCF and CER partition values shows the effective competition by charged surfaces with fish for $A l$ in natural waters. The reduced uptake of $A 1$ by CER in the presence of dissolved organic matter could be due to speciation of $A l$ as negatively charged Al -- organic matter complex species. The 
Table 3. Aluminum Uptake by Fish in the Presence of Competing Compartments

Source of $\mathrm{Al}$

Concentrations of $A 1$ in

water cationic anionic Suspended fish

BCF

resin resin solids

$\mathrm{mg} / 1 \quad \mu \mathrm{g} / \mathrm{g} \quad(\%) \quad(\%) \quad \mathrm{mg} / \mathrm{kg}$

\begin{tabular}{|c|c|c|c|c|c|}
\hline Control River & 0.042 & 4.05 & 0.04 & 9.66 & 8.42 \\
\hline water (NSR) & & $(96)^{*}$ & & & \\
\hline
\end{tabular}

$\begin{array}{lllllll}\text { Aluminum sul- } & 0.290 & 6.10 & 0.05 & 9.67 & 10.41 & 36\end{array}$

phate (21)*

$\begin{array}{lllllll}\text { Alum } & 0.319 & 9.40 & 0.04 & 9.14 & 9.01 & 28\end{array}$

$(29)^{*}$

$\begin{array}{lllllll}\text { Alum Sludge } & 0.202 & 7.86 & 0.04 & 8.15 & 4.6 & 23\end{array}$

alone (39)*

$\begin{array}{lllllll}\text { Alum Sludge } & 0.264 & 5.79 & 0.06 & 7.6 & 8.83 & 34\end{array}$

with $30 \mathrm{ppm}$

$(22)^{*}$

of organic

matter added

(Av:28)

$A v: 30$

$\mathrm{BCF}=$ Bio Concentration Factor

* = Partition Co-efficient between cat. resin/water. 
competition by AER and suspended solids was given in relative terms $(\%)$, since they contained $A l$ as part of their matrices. It has to be pointed out here that the matrix-bound-Al was not leachable under environmentally relevant chemical regimes of $\mathrm{pH}$ and temperature. Only under drastic conditions of digestion with concentrated acids at elevated temperatures (refer Methods and Materials Section), was the Al released from the matrices of $A E R$ and suspended solids.

\subsection{Experiment - II}

In this part of the study, alum sludge kept at the bottom of the tanks and covered by a nylon mesh (Figure 3 ) was the source for Al in all five tanks. Five litres of filtered NSR water was added to each tank and $\mathrm{pH}$ was adjusted to $4.5,6.0,7.65$ (unadjusted natural leve1), 9.0 and 10.0 respectively in tanks $\# 1$ to 5 . $\mathrm{pH}$ values were checked periodically and minor adjustments were made when necessary. Eighteen dialysis sacs, six for each compartment, containing suspended solids, CER and AER were introduced into each tank (Table 2). Twelve fish (20-week-old with average wt. of $1.2 \mathrm{~g}$ ) were introduced into each tank and the automatic rotation of dialysis sacs was started (Time 0 ). The duration of the experiment was $96 \mathrm{~h}$ and the sampling of compartments was at $3,612,24,48$ and 96h. At each sampling time, one sac each of suspended solids, AER, and CER and two fish were removed from each tank for analysis of total Al. In addition $2 \times 110 \mathrm{ml}$ of water was removed from each tank and the $\mathrm{pH}$ value was recorded. One water sample was analyzed for total Al (dissolved + particulate-Al). The 
other water sample was processed for the determination of $\mathrm{Al}$ speciation in each tank as described in the "Methods and Materials Section".

3.3 Speciation of Aluminum (from alum sludge) as a Function of pH

The total concentration and the speciation of Al varied with changes in $\mathrm{pH}$ values of the water column. At an acidic pH of 4.5 , the total Al concentration was about $7.8 \mathrm{mg} / \mathrm{L}$ and the predominant fraction was the particulate-Al (74-75\%), followed by filterableanion-exchangeable (FAEX)-Al (24-20\%), "residual" or filterable-nonexchangeable (FNEX)-Al (2-6\%) and filterable-cation-exchangeable (FCEX)-Al (<\%) (Table 4). Results are not presented for pH 6.0 because turbidity at all sampling times skewed the results. At $\mathrm{pH}$ 7.65 (river water, $\mathrm{pH}$ not adjusted), the speciation of $A 1$ was as follows: FNEX-Al, 62-69\%; FAEX-A1, 23-19\%; particulate- A1, 8-6\% and FCEX-A1, 8-9\% (Table 5). At this pH speciation seems to shift with time; at 6 h FAEX-Al was predominant (53\%), followed by FNEX-Al $(37 \%)$. At pH 9.0 , FNEX-Al $(58 \%)$ and FAEX-Al $(28 \%)$ were the predominant species and at $\mathrm{pH}$ 10.0, FAEX-Al was the predominant species $(95 \%)$.

Aluminum released from the alum sludge was predominantly particulate-bound at $\mathrm{pH} 4.5$, suggesting that $\mathrm{Al}$ was mostly in the free ionic form under acidic conditions and preferred to bind to surfaces. This is consistent with the calculated speciation of $A l$ from the known 
Table 4. Speciation of Aluminum (from Alum Sludge) in Water as a Function of Time and $\mathrm{pH}$

Tank \#1; $\mathrm{pH}=4.50$

concentration of $\mathrm{Al}$ in $\mathrm{mg} / \mathrm{L}$

Species Total Al

(Dissolved \& Particulate Cation-exch. Anion-exch. Residual

$\mathrm{Al}$

Al

$\mathrm{A}]^{*}$

$A 1^{* *}$

$\begin{array}{crrrrrrrrr}3 & 5.23 & 3.86 & (74 \%) & 0.0007 & (0.1 \%) & 1.28 & (24 \%) & 0.12 & (2 \%) \\ 6 & 7.81 & 5.82 & (75 \%) & 0.03 & (0.4 \%) & 1.56 & (20 \%) & 0.47 & (6 \%) \\ 12+ & 21.71 & 17.50 & (81 \%) & 0.01 & (0.05 \%) & 0.89 & (4 \%) & 0.59 & (87 \%)\end{array}$

* Anion-exchangeable Al represents negatively charged weak complex species of Al bound to ligands in water.

** Residual Al includes strongly complexed or chelated Al species (dissolved).

+ Turbidity.

Values in brackets represent percent contribution of the particular species to the total Al.

These footnotes apply to Tables 4 to 7.

Table 5. Speciation of Aluminum (from Alum Sludge) in Water

Tank \#3; $\mathrm{pH}=7.65$

Concentration of $\mathrm{Al}$ in $\mathrm{mg} / \mathrm{L}$

$\begin{array}{lccccc}\text { Species } & \text { Total } & \text { Particulate } & \text { Cation-exch. } & \text { Anion-exch. } & \text { Residual } \\ \text { Time(h) } & \text { Al } & \mathrm{Al} & \mathrm{Al} & \mathrm{Al} & \mathrm{Al}\end{array}$

$\begin{array}{rllllllll}3 & 0.68 & 0.10 & (15 \%) & 0.02 & (3 \%) & -- & 0.90 & \\ 6 & 0.51 & 0.04 & (8 \%) & 0.030(6 \%) & 0.27 & (53 \%) & 0.19(37 \%) \\ 12 & 0.24 & 0.02 & (8 \%) & 0.020(8 \%) & 0.055 & (23 \%) & 0.15 & (62 \%) \\ 24 & 0.13 & 0.02 & (15 \%) & 0.007(5 \%) & -- & & 0.12(92 \%) \\ 48 & 0.18 & 0.015 & (8 \%) & 0.007(4 \%) & 0.015 & (8 \%) & 0.15(83 \%) \\ 96 & 0.16 & 0.01 & (6 \%) & 0.015(9 \%) & 0.03(19 \%) & 0.11(69 \%)\end{array}$


Table 6. Speciation of Aluminum (from Alum Sludge) in Water

Tank \#4; $\mathrm{pH}=9.00$

Concentration of $\mathrm{Al}$ in $\mathrm{mg} / \mathrm{L}$

Species Total Particulate Cation-exch. Anion-exch. Residual

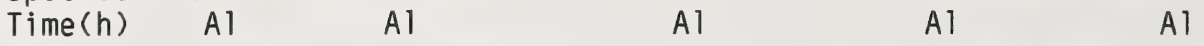

\begin{tabular}{rrrrllllll}
\hline 3 & 20.13 & 17.96 & $(89 \%)$ & 0.030 & $(0.1 \%)$ & 0.60 & $(3 \%)$ & 0.22 & $(1 \%)$ \\
6 & 8.28 & 5.49 & $(66 \%)$ & - & & 2.33 & $(28 \%)$ & 0.18 & $(2 \%)$ \\
12 & 0.24 & 0.02 & $(8 \%)$ & 0.020 & $(8 \%)$ & 0.067 & $(28 \%)$ & 0.14 & $(58 \%)$ \\
24 & 0.45 & 0.02 & $(4 \%)$ & 0.02 & $(4 \%)$ & 0.26 & $(58 \%)$ & 0.11 & $(24 \%)$
\end{tabular}

Tank \#4 was turbid at sampling times, 3,48 and $96 \mathrm{~h}$, again thus yielding inconsistent data for total and particulate Al.

Table 7. Speciation of Aluminum (from Alum Sludge) in Water

Tank \#5; $\mathrm{pH}=10.00$

concentration of $\mathrm{Al}$ in $\mathrm{mg} / \mathrm{L}$

Species Total Particulate Cation-exch. Anion-exch. Residual

$\begin{array}{llllll}\text { Time(h) } & A l & A l & A l & A l & A l\end{array}$

$\begin{array}{ccccccccc}3^{* *} & 117.0 & 97.34 & 0.04 & & 18.01 & & 0.18 & \\ 6 & 21.4 & 0.53(2 \%) & 0.80 & (4 \%) & 21.88 & (102 \%) & 0.23 & (1 \%) \\ 12 & 22.4 & 0.21(1 \%) & 0.05(0.2 \%) & 21.06 & (94 \%) & 0.14 & (1 \%) \\ 24 & 23.5 & 1.73(7 \%) & 0.04 & (0.2 \%) & 21.09 & (90 \%) & 0.14 & (1 \%) \\ 48 & 13.42 & 0.78(6 \%) & 0.04 & (0.3 \%) & 12.76 & (95 \%) & 0.06 & (0.4 \%) \\ 96 & 14.88 & 0.16(1 \%) & 0.06 & (0.4 \%) & 13.217 & (89 \%) & 0.05 & (0.3 \%)\end{array}$

Turbidity caused inconsistent data for total and particulate Al. 
stability constants of its hydroxy complexes, $\mathrm{Al}(\mathrm{OH})^{2+}$,
$\mathrm{Al}(\mathrm{OH})_{2}^{+}$,
$\mathrm{Al}(\mathrm{OH})_{3}^{-}$,
and
$\mathrm{Al}(\mathrm{OH})_{4}^{-}$
(Figure
4).
The partitioning of $A 1$ into the four hydroxy species listed above and the free $\mathrm{Al}^{3+}$ ion was calculated by an iterative procedure using a Fortran Program on an IBM 370 computer. Around neutral pH values (6-8), Al was predominantly in the FNEX species which includes the organo-Al complex (particularly humic and fulvic acid complexes of Al) in the river water and the colloidal $\mathrm{Al}(\mathrm{OH})_{3}^{0}$ species. Our results are in agreement with the results reported for Al speciation in surface waters on the Canadian Pre- Cambrian Shield (Campbell et al., 1984). At alkaline $\mathrm{pH}$ values, $\geqq 8.0$, the speciation of $A l$ shifts gradually from FNEX-Al to FAEX-A1. This is again consistent with the calculated speciation which shows a predominant shift of all species to $\mathrm{Al}(\mathrm{OH})_{4}^{-}$species at $\mathrm{pH} \geqq 8.0$ (Figure 4 ). This shift in speciation from FNEX-Al to FAEX-Al is not affected by the presence of other naturally-occurring complexing agents such as $\mathrm{F}^{-}$, $\mathrm{SO}_{4}^{2-}$, fulvic and humic acids. Computer calculation using the above-mentioned program showed that in a multi-ligand environment, Al exists as $\mathrm{Al}^{3+}$ in acidic $\mathrm{pH}$ values, as complexed species in neutral $\mathrm{pH}$ values and at alkaline $\mathrm{pH}$ values, as $\mathrm{Al}(\mathrm{OH})_{4}^{-}$due to the dissociation of its complexes. Thus, these results from experimental speciation analyses are in good agreement with the calculated speciation in a multi-ligand environment. 
Table 8.

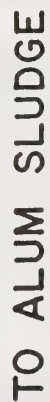

\begin{tabular}{|c|c|c|c|c|c|c|c|c|c|c|}
\hline 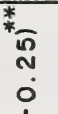 & 这 & $\begin{array}{l}-\overline{0} \\
4 \\
\end{array}$ & $\frac{m}{\dot{m}}$ & $\begin{array}{l}\mathscr{0} \\
\dot{0} \\
\stackrel{\infty}{R}\end{array}$ & $\frac{\text { oे }}{\overline{\bar{m}}}$ & 3 & & & $\begin{array}{l}\stackrel{m}{6} \\
\stackrel{9}{0} \\
=\end{array}$ & \\
\hline $\begin{array}{l}\text { * } \\
\text { *0 } \\
0 \\
0\end{array}$ & 안 & 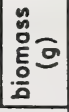 & $\stackrel{\sim}{\infty}$ & $\begin{array}{l}\text { o } \\
\text { के } \\
\Sigma\end{array}$ & $\begin{array}{l}\text { g } \\
\text { Nio } \\
\text { No }\end{array}$ & & & & $\begin{array}{l}\text { m } \\
\stackrel{m}{2} \\
\infty\end{array}$ & \\
\hline$\infty$ & & $\begin{array}{l}5 \\
0 \\
1 \\
1 \\
1\end{array}$ & $\begin{array}{l}\bar{\omega} \\
\stackrel{\sim}{N}\end{array}$ & $\begin{array}{l}\stackrel{\infty}{\dot{\sigma}} \\
\dot{\infty} \\
\dot{\infty}\end{array}$ & $\stackrel{\mathscr{0}}{\frac{0}{\sigma}}$ & & & & 1 & $\tilde{\omega}$ \\
\hline$\stackrel{*}{*}$ & a & $\begin{array}{l}\overline{0} \\
\end{array}$ & $\stackrel{\underline{n}}{\underline{\Sigma}}$ & $\begin{array}{l}\stackrel{n}{\circ} \\
\stackrel{0}{0}\end{array}$ & 尔 & $\stackrel{?}{\stackrel{R}{n}}$ & $\begin{array}{l}\stackrel{0}{\infty} \\
=\end{array}$ & $\frac{\dot{\infty}}{\dot{N}}$ & $\begin{array}{l}\text { d } \\
\text { \& }\end{array}$ & 1 \\
\hline$\frac{1}{*}$ & 안 & है & 邑 & \%ั & $\stackrel{\mathscr{\infty}}{\infty}$ & ஏ & $\hat{m}$ & గొ & $\cong$ & \\
\hline
\end{tabular}

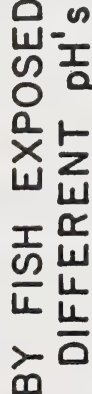

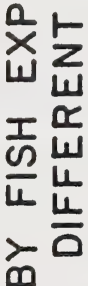

$\infty$

$w<$

1

\begin{tabular}{|c|c|c|c|c|c|c|c|c|}
\hline$\frac{5}{0}$ & $\dot{m}$ & $\because$ & $\ddot{-}$ & $\because$ & $\dot{\sim}$ & $\vec{\sim}$ & $\underline{\underline{m}}$ & 1 \\
\hline 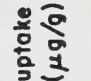 & $\begin{array}{l}\mathscr{\varnothing} \\
\dot{0} \\
\dot{\sigma}\end{array}$ & '̧ & $\underset{\text { ơ }}{\tilde{\sigma}}$ & \begin{tabular}{l}
$n$ \\
\hdashline
\end{tabular} & $\hat{\circ}$ & $\begin{array}{l}\text { ㅇ } \\
\stackrel{0}{0}\end{array}$ & 1 & $\underset{\dot{\varphi}}{\ddot{\theta}}$ \\
\hline
\end{tabular}

u

赵

年宫" :

- I

a

$\frac{1}{0}$

-

든

$\frac{\sum}{2}$

\begin{tabular}{|c|c|c|c|c|c|c|c|c|c|c|}
\hline * & - & ष & $\begin{array}{l}\underset{\infty}{*} \\
\underset{\infty}{*}\end{array}$ & 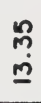 & $\begin{array}{l}\bar{\omega} \\
\sigma\end{array}$ & $\underset{\sim}{N}$ & $\stackrel{N}{\dot{\sigma}}$ & $\stackrel{\mathscr{n}}{\sim}$ & $\begin{array}{l}\text { 우 } \\
\text { के }\end{array}$ & \\
\hline \pm 1 & 우 & 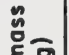 & mo & ஜू & $\stackrel{\sim}{\sim}$ & m & & $\underline{n}$ & กิ & \\
\hline
\end{tabular}

娄

으 응

\& 0 万人

E年

ก 0

D 0 N

ㄴ.

6.

ต - 으 음

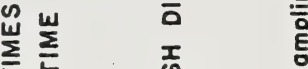

FF 台

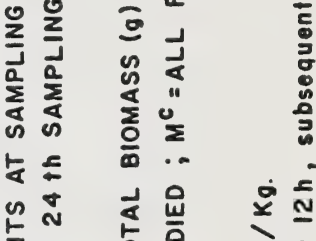

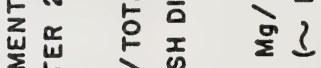

范药

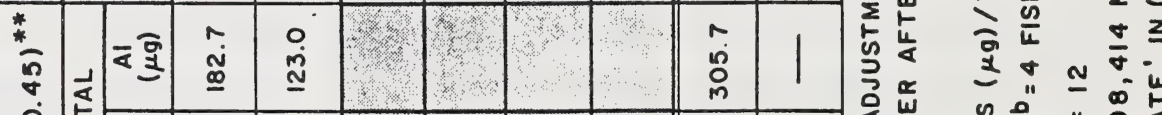

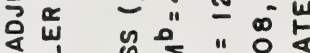

$\sum \sum \underline{5}$

$\sum_{\text {u }} \sum^{5} \cdots x \ldots$

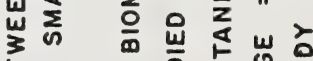

2

\begin{tabular}{|c|c|c|c|c|c|c|c|c|c|}
\hline & $\mid \begin{array}{l} \\
\\
0 \\
0\end{array}$ & $\begin{array}{l}\tilde{N} \\
\boldsymbol{\omega} \\
\text { in }\end{array}$ & $\stackrel{N}{=}$ & 4 & & & & $\begin{array}{l}\text { g } \\
\underline{\omega}\end{array}$ & \\
\hline & 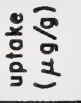 & 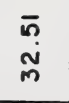 & $\begin{array}{l}\text { 오 } \\
\text { ㅇ }\end{array}$ & & & & & 1 & $\overline{\dot{\infty}}$ \\
\hline & $\bar{\alpha}$ & $\begin{array}{l}\stackrel{n}{0} \\
\dot{\omega} \\
\dot{\infty}\end{array}$ & & & & & & $\begin{array}{l}n \\
\dot{\omega} \\
\dot{\infty}\end{array}$ & \\
\hline & 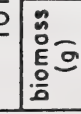 & $\stackrel{\underline{\underline{v}}}{\underline{\underline{v}}}$ & & & & & & $\begin{array}{l}\underline{\underline{\underline{N}}} \\
\underline{\underline{n}}\end{array}$ & 1 \\
\hline & 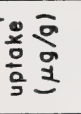 & 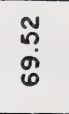 & & $\%$ & & & & 1 & ๑ீ \\
\hline & $F-$ & $m$ & $\boldsymbol{\omega}$ & $\cong$ & $\stackrel{\sim}{\sim}$ & $\stackrel{\infty}{*}$ & $\stackrel{\bullet}{\sigma}$ & $\begin{array}{l}\vec{a} \\
\stackrel{5}{\circ}\end{array}$ & 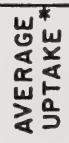 \\
\hline
\end{tabular}

岕岗 z

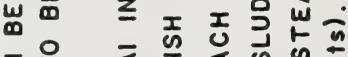

I

z 일

z $\sum_{\text {w }}$ 의

은

的

天

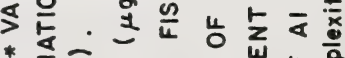

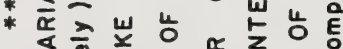

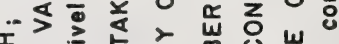

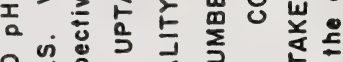

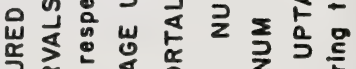

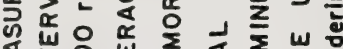

区

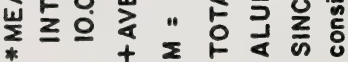


3.4 Uptake of Aluminum (from Alum Sludge) by Fish as a Function of $\mathrm{pH}$ Fish exposed to alum sludge in NSR water whose $\mathrm{pH}$ was adjusted to 4.5 showed significant stress as soon as they were introduced into the tank. The swimming pattern was not normal. Fish spun around aimlessly for about 45 minutes to 1 hour. After 1 hour, fish returned to their normal behaviour including their regular swimming pattern. This behaviour was not noticeable with fish introduced to tanks \#2 to 5 which were held at $\mathrm{pH}>4.5$.

For every sampling time and for each tank, the amount of total Al accumulated $(\mu \mathrm{g})$ by fish, the corresponding total biomass uptake of Al, fish and mortality of fish as a function of $\mathrm{pH}$ are given in Table 8. The average uptake (which is the total Al accumulated during the time course of this experiment divided by the total biomass involved in the uptake) is also given in Table 8 . The average amount of $A 1$ bioconcentrated $(\mu \mathrm{g} / \mathrm{g})$ at $\mathrm{pH}$ values 6.0 and 7.65 are 3 and 18 times lower than the amount bioconcentrated at pH 10.0. Of course, at the extreme $\mathrm{pH}$ values of this experiment, namely, 4.5 and 10.0 , there were fish mortalities.

Since most of the Al was particulate-bound at $\mathrm{pH} 4.5$, it is likely that the fish died of acid stress. The initial stress symptoms shown by fish on introduction to this $\mathrm{pH}$ value supports this suggestion for fish mortality. High levels of $A l$ in fish at pH 4.5 even at $3 \mathrm{~h}$ exposure could not have been the cause for their mortality because fish with higher concentrations of $A l$ at $\mathrm{pH} 10.0$ did survive at $6 \mathrm{~h}$ exposure. Turbidity alone could not have been the cause for fish 


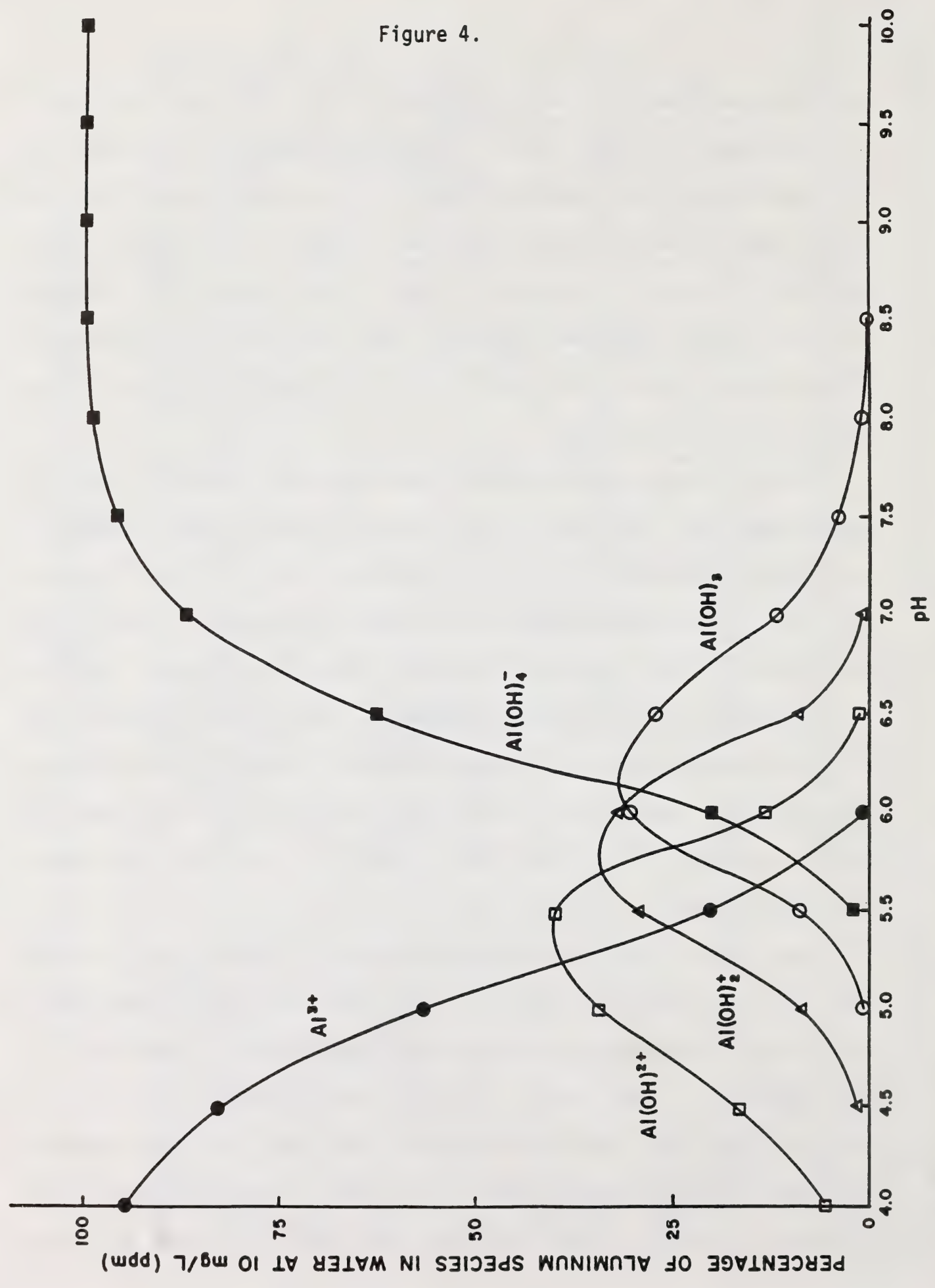


mortality in tank \#2 ( $p H, 6.0)$ because tank \#4 ( $p H, 9.0)$ was turbid throughout the experiment and yet there was no mortality of fish at any time. This leads to the suggestion that the filterable-cation-exchangeable-Al (FCEX-Al) was probably the toxic species. At this $\mathrm{pH}(6.0)$, the predominant species would be $(\mathrm{AlF})^{2+}, \quad \mathrm{Al}(\mathrm{OH})^{2+}, \quad\left(\mathrm{AlSO}_{4}\right)^{+}, \quad \mathrm{Al}(\mathrm{OH})_{2}^{+}, \quad\left(\mathrm{AlF}_{2}\right)^{+}$and $\mathrm{Al}(\mathrm{OH})_{3}^{0}$ ions, some of which are considered to be toxic to freshwater algae, Chlorella pyrenoidosa. Helliwell et al. (1983) showed that $\mathrm{Al}(\mathrm{OH})^{2+}$ or a combination of $\mathrm{Al}(\mathrm{OH})^{2+}$ and $\mathrm{Al}(\mathrm{OH})_{2}^{+}$ are the species toxic to the alga, Chlorella pyrenoidosa (Figure 5). A large excess of complexing agents such as salicylic acid, fulvic acid, phosphate, fluoride, and sulphate ions have been reported to significantly reduce the toxicity of $A l$ towards algae in synthetic hard water at $\mathrm{pH}, 5.2$, containing total Al of $30 \mathrm{ug} / \mathrm{L}$ (Helliwell et al., 1983).

These experiments showed that the FNEX-Al and FAEX-Al were not toxic to fish in the $\mathrm{pH}$ range 7.65 to 9.0 and the amount of $\mathrm{Al}$ bioconcentrated was lower than the amount at the other three pH values (acidic, 10.0 and 6.0 ) (Table 8). It should be noted that although loading densities exceeded known standards, there was no indication the fish were stressed in any experiment.

3.5 Effect of Competing Compartments on the Uptake of Aluminum by Fish Tank \#3 (pH, 7.65) with filtered NSR water in Experiment-II was comparable to tank \#4 in Experiment-I in terms of experimental 
conditions. The only exception was that a new batch of alum sludge was used in Experiment-II (AI concentration $=108,414 \mathrm{mg} / \mathrm{kg}$ of sludge). The actual amount of $A l$ bioconcentrated in both cases ( $\mathrm{pH}$, 7.65) was reasonably close to each other ( 3.4 and $4.6 \mathrm{mg} / \mathrm{Kg}$ wet $w t$ ). It has be pointed out here that the amount of Al bioconcentrated was the lowest at the natural pH value and increased with $\mathrm{pH}$ changes on either side of $\mathrm{pH} 7.65$, reaching a maximum at extreme $\mathrm{pH}$ values of 4.5 and 10.0 (Table 9). The amount of $A 1$ in fish was about 20 times higher at pH 4.5 and $\mathrm{pH} 10.0$ (69.52 and $62.0 \mathrm{mg} / \mathrm{Kg}$ wet wt).

Cationic surfaces (CER) competed effectively with fish for the uptake of $A l$ at $\mathrm{pH}, 4.5$. In fact, the partition coefficient was slightly higher than the corresponding BCF and also the actual amount of Al accumulated (Table 9). At $\mathrm{pH} \geqq 7.65$, Al partitioned favourably with AER (Table 9). Relatively higher competition by AER (6-10 times compared to BCF, Table 2) in the $\mathrm{pH}$ range 7-9, minimized the amount of Al bioconcentrated by fish. Incidentally, there were no mortalities in this $\mathrm{pH}$ range. 


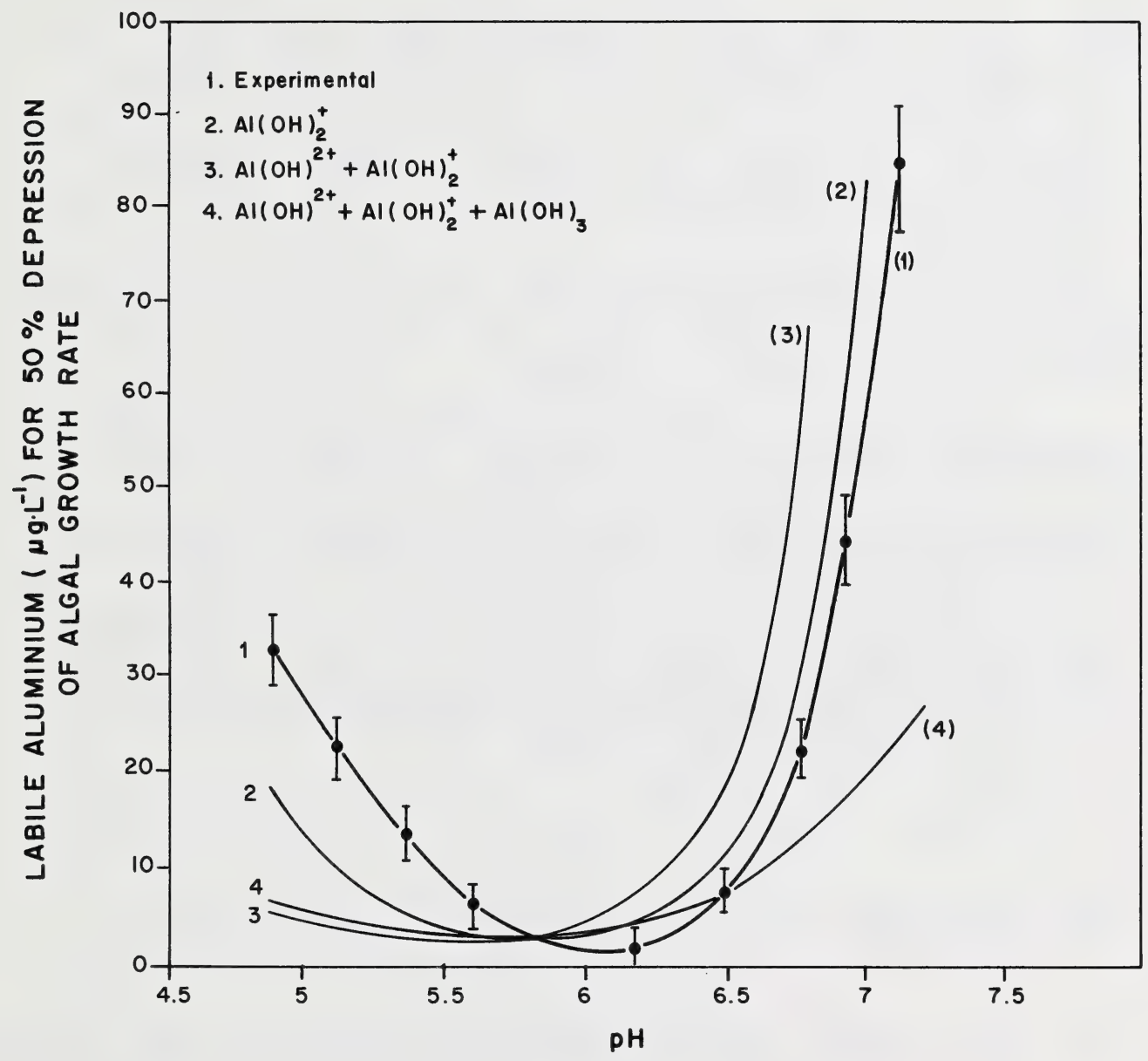

Figure 5.

Curve 1. Experimental labile aluminum-pH curve for $50 \%$ depression of algal growth rate (toxicity curve).

Curves 2-4. Calculated toxicity curves, using the data in Figure 2, and fitting to the experimental toxicity curve at $\mathrm{pH} 5.8$. [From: Helliwell et al. (1983)] 
Table 9. Aluminum Uptake by Fish exposed to Alum Sludge at varying $\mathrm{pH}^{\prime} \mathrm{s}$ and in the presence of Competing Compartments

Exposure

Concentration of Aluminum in

BCF

$\mathrm{pH}$ Water Cation resin Anion resin Susp.solids Fish $\mathrm{mg} / \mathrm{L} \quad \mathrm{\mu g} / \mathrm{g} \quad \% \quad \% \quad \mathrm{mg} / \mathrm{kg}$

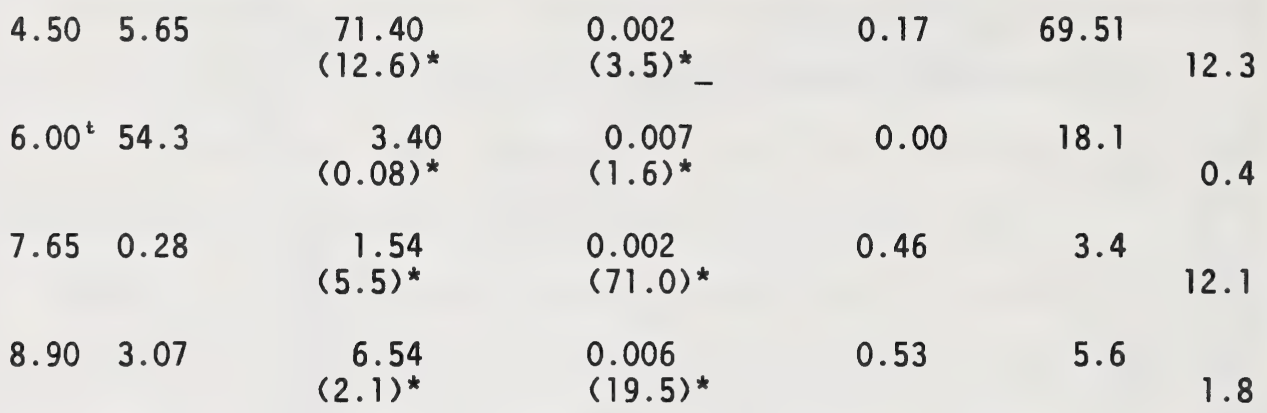

9.8015 .66

19.28

$(1.2)^{*}$

0.02

$(12.8)^{*}$

0.36

62.0

4.0

$B C F=$ Bio Concentration Factor

* = Partition Coefficient between the compartment and water.

$t$ = turbidity at all sampling times.

4.0 CONCLUSIONS

4.1 These studies show that aluminum is effectively bound in the sludge at all pH values from 4.5 to 10.0 , the sludge releasing less than $0.02 \%$ of its total Al content.

4.2 However, relatively higher levels of $A l$ are released at extreme $\mathrm{pH}$ values of 4.5 and 10.0 . 
4.3 Environmentally significant compartments such as suspended solids, cationic and anionic exchange surfaces compete effectively with fish in the uptake of $\mathrm{Al}$.

4.4 The uptake of $\mathrm{Al}$ by fish reaches a "steady state" in $48 \mathrm{~h}$ and the maximum amount bioconcentrated in natural $\mathrm{pH}$ values $(7.6)$ is $\sim 9$ $\mathrm{mg} / \mathrm{Kg}$ wet weight regardless of the source of $\mathrm{Al}$.

4.5 Speciation studies showed that aluminum exists as $\mathrm{Al}^{3+}$ ions in acidic pH, as complexed (Filterable-Non-Exchangeable)-Al species in neutral pH and as $\mathrm{Al}_{(\mathrm{OH})_{4}^{-}}$(Filterable-AnionExchangeable)-Al species in alkaline $\mathrm{pH}$.

4.6 This speciation data could be used by waterworks engineers and aquatic toxicologists with the knowledge of the species they have to deal with at the chosen $\mathrm{pH}$. It may be desirable to discharge the alum sludge during periods of high suspended solids load or mixing it with naturally occurring polyelectrolytes of plant origin prior to discharge to minimize the exposure concentration of Al to fish in natural waters. The aquatic toxicologists can interpret their effect data better by correlating to the correct species of Al present under the conditions of the experiment. 


\section{REFERENCES}

Annual Book of ASTM Standards, Philadelphia, Penn. U.S.A. Part 31, 276-282 (1980).

Campbe11, P.G.C., Bougie, R., Tessier, A. and Villeneuve, J.P. Verh.

Internat. Verein. Limnol. 22: 371-375 (1984).

Helliwell, S., Batley, G.E., Florence, T.M. and Lumsden, B.G.

Environ. Technol. Letters, 4: 141-144 (1983).

Methods of Chemical Analysis of Water and Wastes, USEPA,

Environmental Monitoring and Support Laboratory, Cincinnati, U.S.A., EPA-600/4-79-020, Method 202 (1979).

Ramamoorthy, S. and Leppard, G.G. J. Theor. Biol. 66, 527-540 (1977).

Schnitzer, M., and Skinner, S.I.M., Soil. Sci. 103: 247 (1967). 
PART III

ALUM SLUDGE TOXICITY IN FISH

by

M. ALBASSAM, J.W. MOORE

AND A. MUTALIB

Animal Sciences Wing 

SUMMARY

The purpose of this study was to determine the acute and subacute toxicity to fish of alum sludges produced by different water treatment plants. Alum sludges were collected from Rossdale, E.L. Smith and Glenmore plants at different times and were applied at different concentrations. Acute toxicity was measured using the $96 \mathrm{~h} \mathrm{LC}_{50}$ rainbow trout bioassay. Subacute toxicity was determined by exposing fish to alum sludge for 96 hours after which the tanks were flushed with treated municipal water and the fish were left for another 96 hours.

All fish were submitted for histopathological evaluation. Blood analysis and electron microscopy were also conducted on fish used in the subacute study. Based on these experiments, it can be concluded that:

1. The sludges were not acutely toxic to rainbow trout. In general, fish were able to survive for $96 \mathrm{~h}$ in $100 \%$ sludge (no diluent added).

2. No significant toxicological alterations were observed in the tissues from the exposed fish.

3. No significant changes were observed in the blood parameters, including electrolytes, gases and $\mathrm{pH}$.

4. No evidence for accumulation of aluminum was observed in the gills. 


\section{INTRODUCTION:}

The deposition of alum sludge into surface waters has the potential of affecting the survival of fish. Apart from the possibility of mortality, there may also be damage to fish tissues and changes in blood parameters and enzyme activity. This in turn may alter the productivity and reproduction of fish in receiving waters. At present, there is no information available on the toxicity of alum sludge to fish in Alberta but reviews have been published on sludges from other parts of the world (Odonnell et al., 1984). In this study, the acute and subacute toxicity of sludge from the Edmonton and Calgary treatment plants to rainbow trout was determined. 


\section{MATERIALS AND METHODS}

\subsection{Acute Toxicity}

Acute tests were conducted in recycle exposure chambers as illustrated in Figure 1. These chambers were specifically designed to permit the continuous suspension of solid material. Particles that settle are drawn by a pump from the bottom of the chamber to the surface of the water, where they gradually resettle. Each chamber had a dilution volume of 20 litres. Plastic mesh was placed over the tops of the chambers to prevent the fish from jumping.

Acute toxicity was measured using the $96 \mathrm{~h} \mathrm{LC}_{50}$ rainbow trout bioassay. Groups of ten fish (4-8 cm fork length) were exposed to five different concentrations of alum sludges (Table 1). A control group of ten fish for each sludge was left in treated municipal water. All fish were starved for two days prior to the start of the test and were not fed throughout the test. This stabilizes their metabolic rate and minimizes organic matter buildup in the test vessels.

Observations for potential mortality were made at the start of the test and at 15 minutes, 30 minutes, 1 hour, 2, 4, 8, 24, 48, 72 and 96 hours. Fish were considered dead when there was no respiratory or other movement and no response to gentle prodding.

Moribund or dead fish during this 96 hour period were submitted for histopathological examination. In addition at least five of the fish remaining at the end of the $96 \mathrm{~h}$ period were also examined for evidence of histopathological changes. 


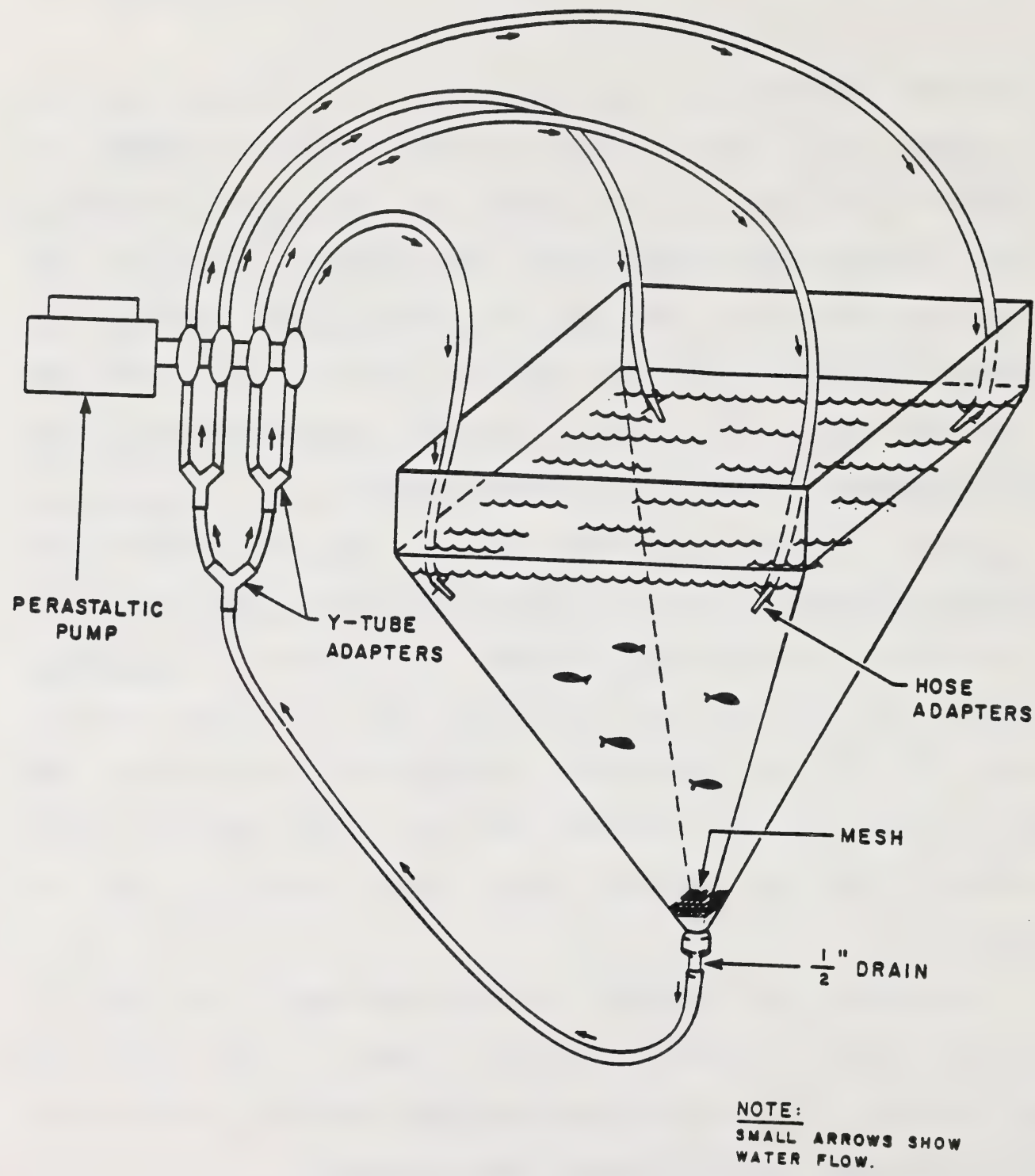

Figure 1. Chambers used for acute toxicity bioassay. 
Table 1. Concentrations of different alum sludges used in the acute toxicity study*.
Alum Sludge Concentration $\%$
Rossdale (first collection)
plant \#1 $1,10,50,75,100$
plant \#2 $1,10,50,75,100$

Rossdale (second collection)

plant \#1 $\quad 1,10,50,75,100$

E.L. Smith (first collection)

$C_{1} \quad 1,10,50,75,100$

$\mathrm{C}_{2} \quad 1,10,50,75,100$

Glenmore (first collection)

$1,10,50,75,100$

*These concentrations were adjusted in treated municipal water

\subsection{Subacute Toxicity}

Four groups, of ten large $(20-30 \mathrm{~cm}$ fork length) fish each, were exposed to $10 \%$ concentration of four different alum sludges obtained from Rossdale \#1, E.L. Smith $\left(C_{1}\right.$ and $\left.C_{2}\right)$ and Glenmore plants. Exposure to alum sludge was carried out in 682 litre tanks. The exposure period was initially for 96 hours, after which treated municipal water was passed through the tanks at a rate of 14 litres/minute for about five hours. After this flushing the fish were left in treated municipal water for another 96 hours. Another two groups of ten fish served as control and were left in the treated municipal water during the two 96 hour periods of the test. 
Immediately before flushing, five fish were removed from each group for hematological and histopathological studies. The remaining fish were submitted for these examinations at the end of the second 96 hour period.

Observations for potential mortality were made at the start of the test and after 15 minutes, 30 minutes, 1 hour, $2,4,8,24,48$, 72, 96, 120, 144, 168, 192 and 216 hours. Table 2 gives concentrations of alum sludges used in this study.

Table 2. Concentrations of alum sludges used in the subacute toxicity test.

Alum Sludge Source
Concentrations

$\%$

Rossdale plant

\#1

10

(second sample collection)

E.L. Smith plant

$C_{1}$

$\mathrm{C}_{2}$

(second sample collection)

Glenmore plant

(first sample collection)

\subsection{Histopathology}

Histopathology was carried out in both acute and subacute studies. Small fish were first slit open at the abdomen and 
immediately placed in the fixative. Large fish were routinely necropsied and selected tissues were collected and placed in the fixative. Bouin's solution was used as a fixative for the first 24 hours, tissues were then preserved in $50 \%$ alcohol until trimming.

Tissues were routinely processed and sections of five to six microns in thickness were prepared and stained with hematoxylin and eosin. Gills, heart, oral cavity, eye, brain, liver, stomach, pyloric ceca, intestine, pancreas, spleen, anterior and posterior kidneys, gonads, skin and muscle were examined in each fish.

\subsection{Electron Microscopy}

Fish gill tissues were collected after 96 and 192 hours exposure of 10\% Rossdale, $10 \%$ Glenmore, $10 \%$ E.L. Smith along with respective controls. Two approaches were taken to analyze fish gill tissue with the electron microscope (EM).

a) Analysis at cellular level: Fish gill tissues were fixed in glutaraldehyde, dehydrated with organic solvents and embedded in Epon. Ultrathin sections were analyzed with the scanning transmission electron microscopy mode coupled with energy dispersive x-ray analysis.

b) Direct analysis: Processing of samples by conventional methods as described in section (a) often causes extraction, introduction and redistribution of elements as the tissues 
are treated with organic solvents and embedding material. In order to minimize these factors and obtain true elemental composition, the gill tissues were also analyzed by a direct method. The gill tissue was ground with a mortar and pestle and placed on an electron microscope grid for direct elemental analysis. An electron probe of 10 to $100 \mathrm{~nm}$ was placed at 12 random locations on the dark homogeneous (as it appeared in the STEM mode) ground gills. Average counts from 12 analyses per group were calculated and comparison was made between the control and experimental groups.

\subsection{Hematology}

These studies were done on the large fish only. Immediately after stunning the fish, $1-3 \mathrm{ml}$ of blood was collected by cardiac puncture using a 22 gauge needle attached to a $3 \mathrm{ml}$ syringe containing traces of heparin. The blood was immediately analyzed for a number of parameters as outlined below:

1. Hematocrit

2. Blood oxygen using a Clark-type electrode

3. Carbon dioxide using a Severinghaus-Stow type electrode

4. pH by flow-through glass capillary and reference assembly

5. Total carbon dioxide, bicarbonate and base excess were calculated by the machine based on the Henderson-Hasselbach equation. 
The above parameters were carried out using Corning pH/blood gas 178 analyzer.

All measurements and calculations of the analyzer were corrected according to body temperature of the fish $\left(12^{\circ} \mathrm{C}\right)$ and hemoglobin values (9.0 gm/dl) using Kelman and Numm formula.

6. The remaining blood was then centrifuged and the plasma was harvested for chemical analysis. The following parameters were examined:

A) plasma sodium $\left(\mathrm{Na}^{+}\right)$and potassium $\left(\mathrm{K}^{+}\right)$by flame photometry.

B) Chloride $\left(\mathrm{Cl}^{-}\right)$by modified Schoenfeld and Lawellen method.

C) Glucose: glucose oxidase by modified Trinder method.

D) Total protein by refractometry and biuret methods.

E) Aspartate amino transferase (AST) and alanine amino transferase (ALT).

The above tests were carried out using the KDA multichannel analyzer, American Monitor Corporation, Downsview, Ontario.

The sampling and analytical techniques can be expected to have altered the above parameters. Capture and blood sampling probably decreased blood $\mathrm{pH}$ and $\mathrm{PO}_{2}$ and increased $\mathrm{CO}_{2}$ via metabolic acid production and branchial failure upon removal of the fish from the water. Warming of blood from $12^{\circ} \mathrm{C}$ to $37^{\circ} \mathrm{C}$ for measurement purposes will alter $\mathrm{pH}, \mathrm{O}_{2}$ and $\mathrm{CO}_{2}$ values. Using human-derived correction 
factors to back-adjust the resultant measurements to $12^{\circ} \mathrm{C}$ may have led to some error. This is especially true for $\mathrm{PO}_{2}$ values because fish blood exhibits both Bohr and Root shifts, whereas human blood exhibits only Bohr shifts. $\mathrm{PCO}_{2}$ values generated using the above technique must also be treated with caution because the expected values for fish blood (1-4 torr) are well outside the calibration range of the analyzer (about 35-70 torr).

\subsection{RESULTS}

\subsection{Histopathology of Small Fish}

Histopathological lesions in small fish were mostly concentrated in the gills. Gill lesions extended from mild to moderate and were characterized by hypercellularity, shortening and fusion of the secondary lamellae. These lesions were seen in 75 out of 140 exposed fish as well as in 13 out of 30 control fish.

Incidental findings were also seen; hepatic fatty changes were seen in one fish, dermatitis (one fish) and myositis (one fish). Table 4 gives a summary of histopathological findings and Appendix I gives details of these findings. 
Table 3. Acute Toxicity Test Results

$\begin{array}{llc}\text { Test Pathology Fraction } & \begin{array}{c}\text { Concentrations } \\ \text { Tested }\end{array} & \text { Results } \\ \text { No. Access No. Tested } & \text { Tos } & \end{array}$

77-84 1726-84 Rossdale Plant control, $1,10,50,75,{ }^{*} 20 \%$ mort in $10 \%$ 79-84 1788-84 $\begin{array}{lll}\# 1 & \text { Rossdale Plant } & 100 \\ \text { control, } 1,10,50 * 30 \% \text { mort in } 75 \%\end{array}$

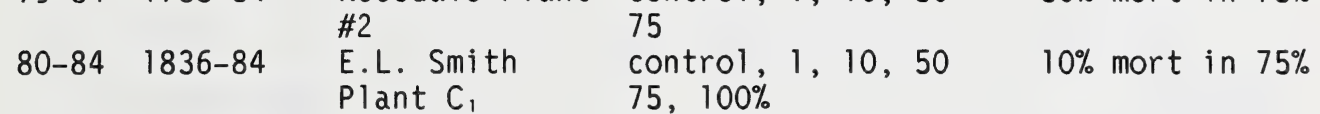

81-84 1943-84 E.L. Smith control, 1, 10, $50 \quad 10 \%$ mort in $75 \%$

88-84 1964-84 Glenmore Plant control, 1, 10, 50* $10 \%$ mort in $1 \%$ Calgary (1 of $9 \mathrm{fish}$

only)

$11 \%$ mort in $75 \%$ $20 \%$ mort in control

$40 \%$ mort in $10 \%$ $20 \%$ mort in $50 \%$

$10 \%$ mort in $100 \%$

*Due to problems with the turbidity of the sample reliable results were not obtained for the noted concentrations. 
Table 4.

Histopathological lesions in small fish exposed for $96 \mathrm{~h}$ to different concentrations of different alum sludges

\begin{tabular}{|c|c|c|c|c|c|}
\hline \multirow{3}{*}{\multicolumn{2}{|c|}{$\begin{array}{l}\text { Alum } \\
\text { Sludge }\end{array}$}} & \multicolumn{3}{|c|}{ Gill lesions* } & \multirow[t]{3}{*}{ Gill lesions** } \\
\hline & & MI & MO & $\begin{array}{l}\text { fish with } \\
\text { lesion(s) }\end{array}$ & \\
\hline & & & & total & \\
\hline \multirow{3}{*}{$\begin{array}{l}\text { Rossdale } \\
\# 1 \text { (first } \\
\text { collection }\end{array}$} & 1 & - & - & - & \multirow{3}{*}{$\begin{array}{l}\text { Not submitted } \\
\text { for histopath. } \\
\text { Two; } 1 \text { mild, } \\
1 \text { autolyzed }\end{array}$} \\
\hline & n) 10 & 2 & 0 & $2 / 3$ & \\
\hline & $\begin{array}{c}50 \\
75 \\
100 \\
\text { Control }\end{array}$ & $\begin{array}{l}0 \\
2 \\
0 \\
3\end{array}$ & $\begin{array}{l}0 \\
0 \\
0 \\
0\end{array}$ & $\begin{array}{l}0 / 5 \\
2 / 5 \\
0 / 5 \\
3 / 5\end{array}$ & \\
\hline
\end{tabular}

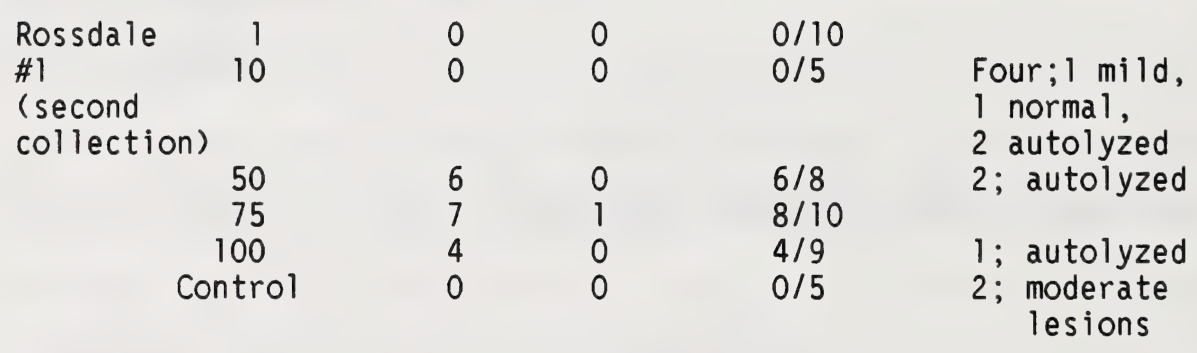

$\begin{array}{lrrrr}\text { Rossdale } & 1 & 1 & 3 & 4 / 5 \\ \text { plant \#2 } & 10 & 3 & 2 & 5 / 5 \\ \text { (first } & 50 & 2 & 0 & 2 / 2 \\ \text { collection) } & 75 & 1 & 1 & 2 / 2 \\ & 100 & & & \end{array}$

Control

$\begin{array}{lll}0 & 1\end{array}$

5; autolyzed

3 , autolyzed not submitted for histopathology

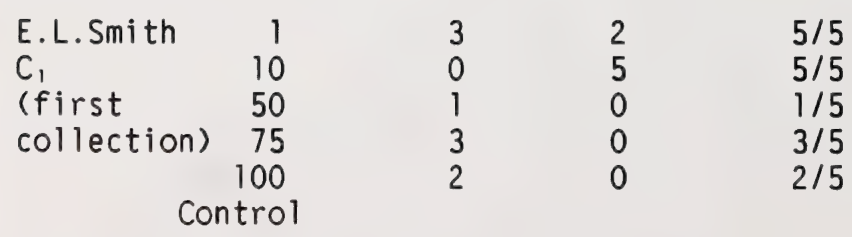


Table 4. Continued.

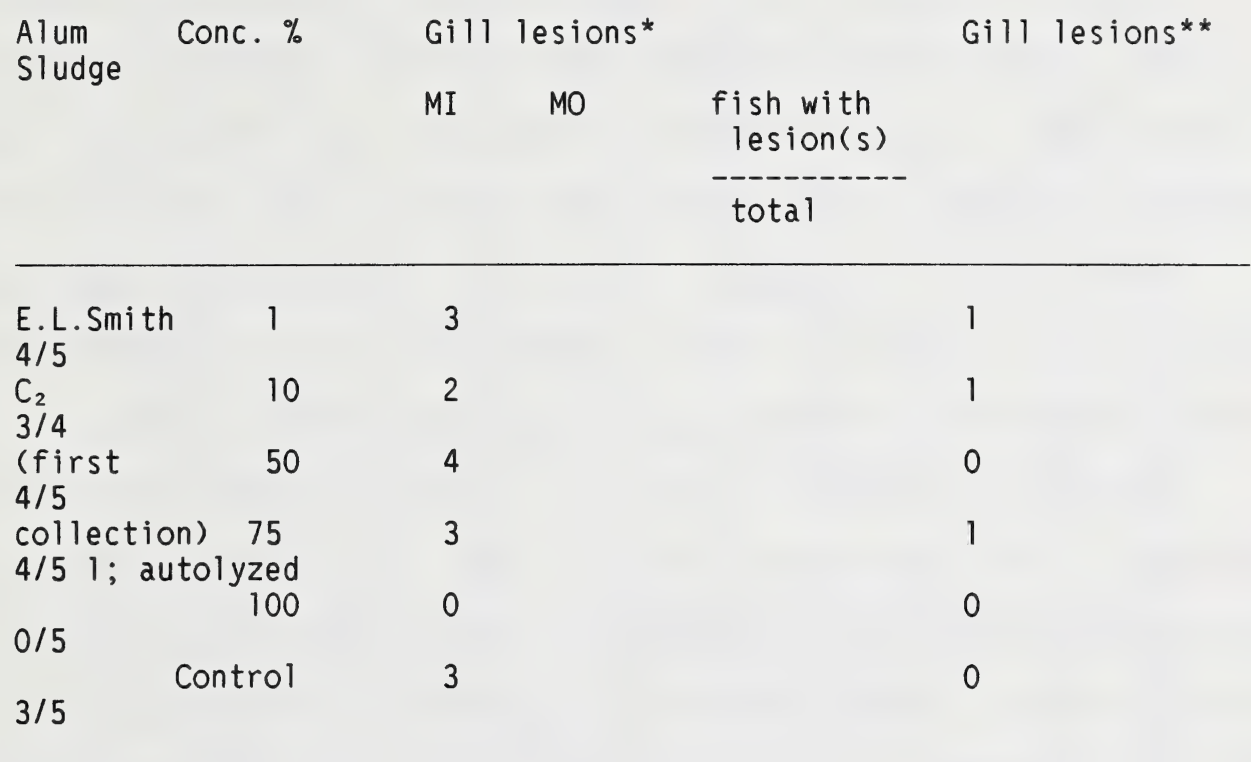

\begin{tabular}{|c|c|c|}
\hline $\begin{array}{l}\text { Glenmore } \\
2 / 51 \text {; autolyzed }\end{array}$ & 2 & 0 \\
\hline (first 10 & 2 & 0 \\
\hline $\begin{array}{l}2 / 5 \\
\text { collection) } 50 \\
4 / 5\end{array}$ & 3 & 1 \\
\hline $\begin{array}{c}75 \\
3 / 51 ; \text { autolyzed } \\
100 \\
\text { Nine; } 4 \text { no significant }\end{array}$ & 2 & 1 \\
\hline $\begin{array}{l}\text { lesion, } 5 \text { autolyzed } \\
\text { Control } \\
4 / 5\end{array}$ & 3 & 1 \\
\hline
\end{tabular}

Conc. $\%=$ Concentration $\%$

MI $=$ Mild

MO = Moderate
${ }^{*}$ Gill lesions in terminally killed fish

**Gill lesions in fish dying during the experiment 


\subsection{Histopathology of Large Fish}

Lesions were mostly seen in the gills and incidentally in other tissues. Gill lesions extended from mild to moderate and were characterized by hypercellularity, shortening and fusion of the secondary lamellae. These lesions were seen in a total of 25 out of 39 exposed fish. Incidental findings included mild to moderate hepatic fatty changes ( 3 fish), gastritis ( 3 fish), dermatitis ( 3 fish), lymphocytic pericarditis and necrotic myocarditis ( 9 fish).

Similar gill lesions were seen in 10 out of 19 control fish. In addition, other incidental findings were also seen; necrotic myocarditis ( $8 \mathrm{fish}$ ), fatty changes ( $2 \mathrm{fish}$ ), gastritis ( 1 fish). A unique incidental lesion was seen in the stomach of two control fish and was described as perineuritis. This lesion was characterized by lymphocytic infiltration and fibrosis around the nerve. Table 5 gives a summary of histopathological lesions in large fish and Appendix II gives the details of these findings. 


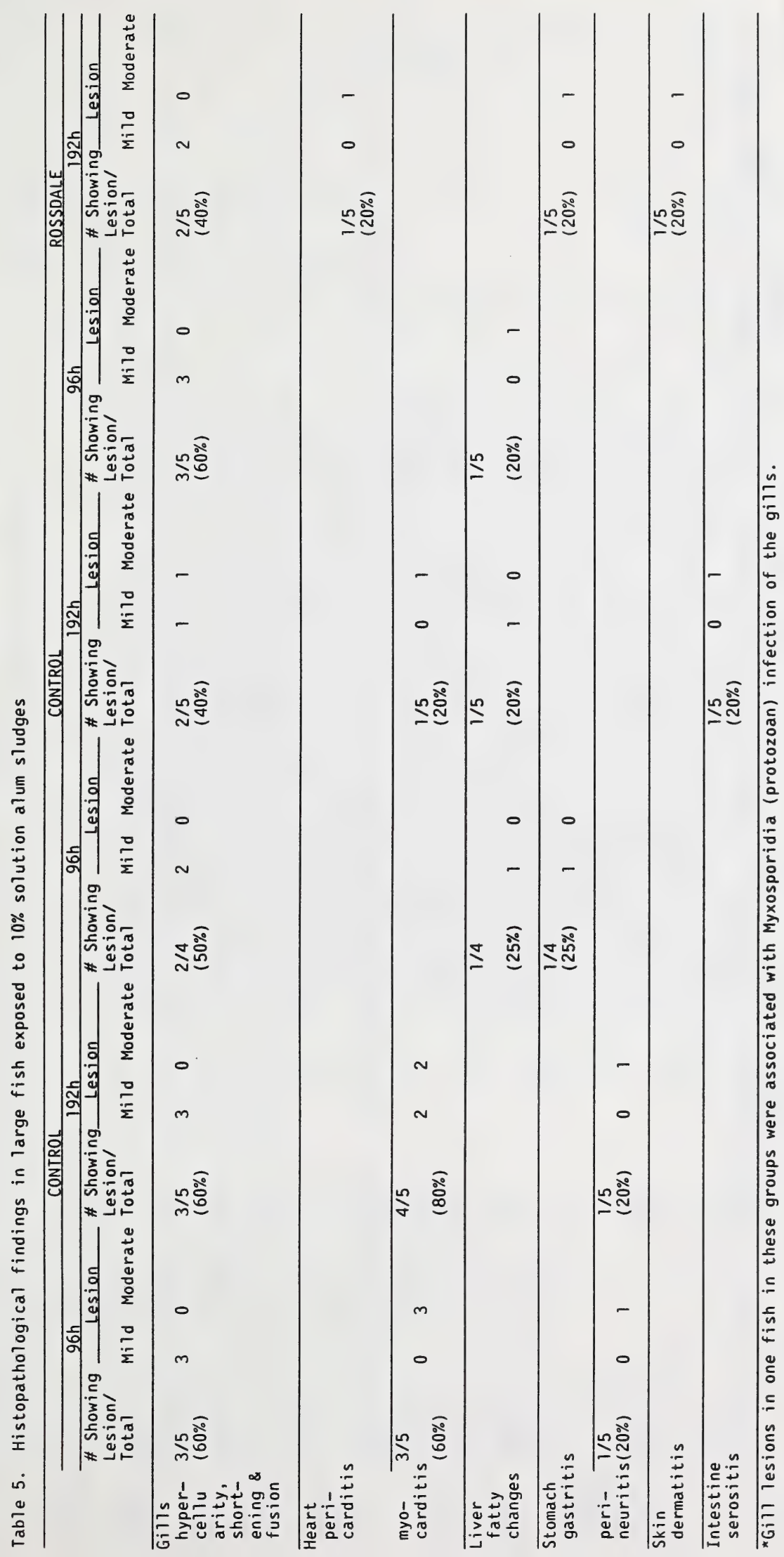




\subsection{Electron Microscopy}

A. Analysis at cellular level

When an electron probe of 10 to $100 \mathrm{~nm}$ was placed on the thin sections of the surface of gill lamallae, emission spectra were collected in duplicate from the nucleus, cytoplasm, electron dense structures and surface fibrils. Elements such as silica, chlorine, iron, lead and uranium were detected in the experimental and control tissues. No evidence was obtained for the presence of aluminum at the ultrastructural level. Chlorine, lead and uranium peaks were presumably due to the processing chemicals used.

B. Direct analysis

The results obtained by this procedure showed presence of phosphorus, sulfur, potassium, calcium, iron and silica in the experimental and control groups. Occasionally, the presence of zinc, nickel, magnesium and chlorine were also detected in these groups. No significant peaks for aluminum were detected.

The results obtained by the above approaches are in agreement, and the present evidence suggests that the aluminum in fish gill tissue is not detectable by these procedures. 


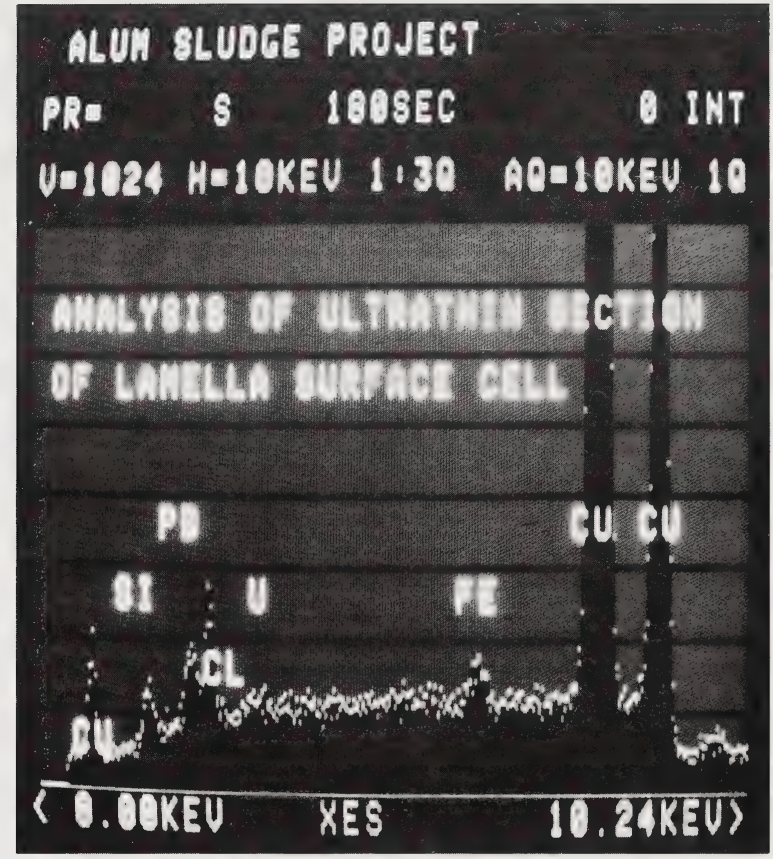

Figure 2. X-ray spectrum showing elemental analysis of the electron dense structures in ultrathin section of the surface cells of the gill lamella. 
(66)

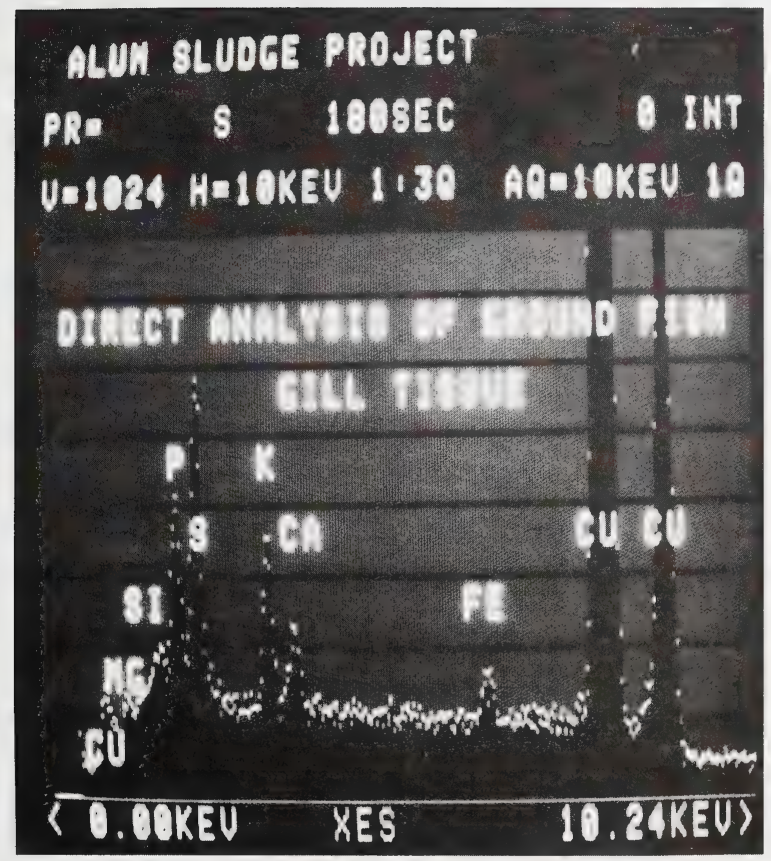

Figure 3. X-ray spectrum showing elements detected by direct analysis of ground fish gill tissue. 


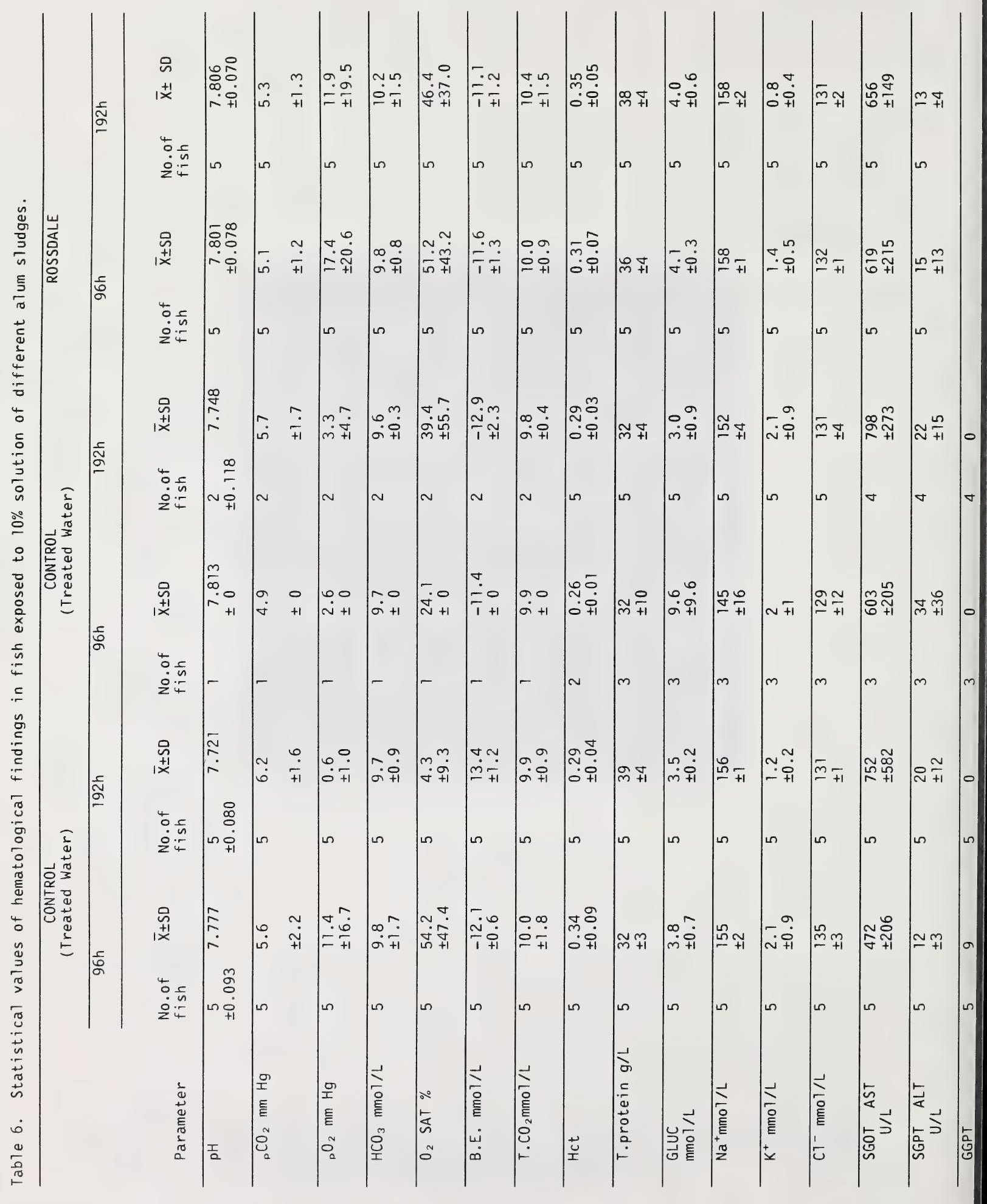




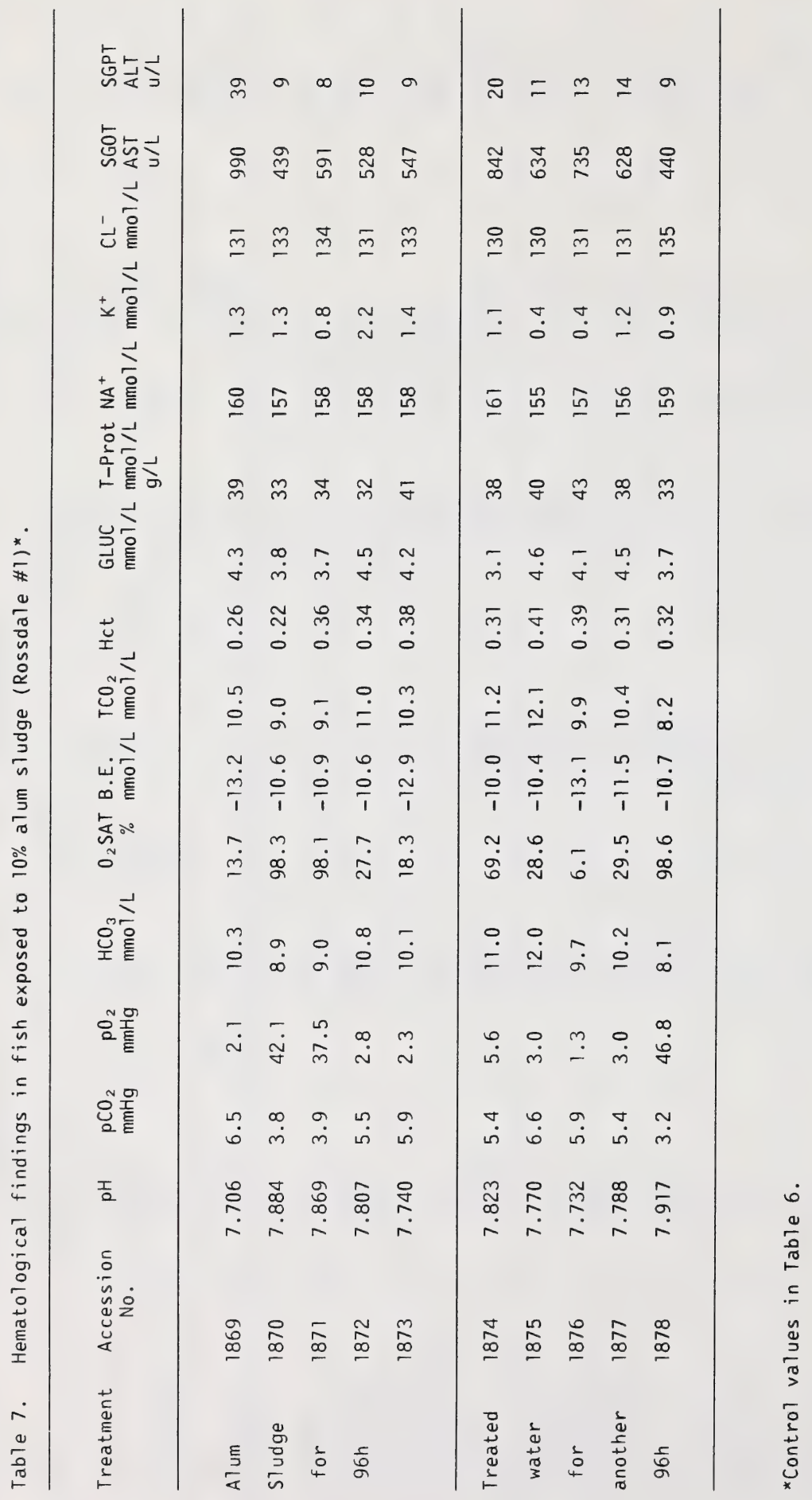




\subsection{DISCUSSION}

Histopathological lesions were seen in the gills of the principal and control groups. There was no correlation between gill changes and exposure to alum sludge. There was no evidence for the accumulation of aluminum in the gills when these tissues were examined by electron microscopy. Moreover, no significant changes were detected in the blood of these fish. Therefore alum sludges were considered to be not acutely or subacutely toxic to fish at the test concentrations.

\section{REFERENCE}

Odonnell, A.R., G. Mance, and R. Norton. 1984. A review of the toxicity of aluminum in freshwater. Water Research Centre. TR 197. $27 \mathrm{pp}$. 
Appendix I. Histopathological findings in small fish (Acute Study).

Accession \#1596-84

24 hour exposure to $10 \%$ anaerobic alum sludge. 5 fish were examined.

Liver: Mild diffuse hepatic fatty changes (l fish).

Rossdale \#1 (First collection)

Accession \#1726-84

A - Control

Gills: Mild hypercellularity and fusion of secondary lamella. These lesions were seen in 3 out of 5 examined fish.

Liver: Mild diffuse hepatic fatty changes were seen in one fish.

No other significant histologic lesion was seen in the examined tissues.

B - $1 \%$ - No fish submitted for histopathology.

C- $10 \% \quad C_{1}-C_{2}$ two fish died interim.

C, Marked autolysis.

$C_{2}$ Moderate necrosis, swelling and sloughing

of pavement epithelial cells.

$\mathrm{C}_{3}$ Three fish terminally killed. 
Gills: hypercellularity and fusion of secondary lamellae

$$
\begin{aligned}
& 2 \text { - mild } \\
& 1 \text { - normal }
\end{aligned}
$$

D $-50 \%$

5 fish - terminal kill

No significant lesion was seen in the examined tissues.

$E-75 \%$

The final concentration was about $37.5 \%$ due to contamination with $1 \%$ solution.

5 fish - terminal kill

Gills: Hypercellularity and fusion of the secondary lamellae.

Mild: 2

F. $100 \%$

5 fish - terminal kill

No significant lesion was seen in the examined tissues.

Rossdale plant \#1 (second collection)

Accession \#2340-84

A - Control

$A_{1}-A_{2} 2$ fish interim death

Gills: shortening and fusion of secondary lamellae Moderate - 2 
A3 - 8 fish terminal kill

No significant lesion was seen

B $1 \%$ - 10 fish terminal kill.

No significant lesion was seen

C: $10 \%$

$C_{1}-C_{3} 4$ fish interim death

Gills: hypercellularity of secondary lamellae

Mild 1

Normal 1

2 fish were markedly autolyzed.

$\mathrm{C}_{4}-5$ fish terminal kill

No significant lesions were seen.

D $-50 \%$

$D_{1}-D_{2}-2$ fish interim death

Tissues were autolyzed and unsuitable for evaluation.

$\mathrm{D}_{3}-8$ fish terminal kill

Gills: hypercellularity and fusion of secondary lamellae

Mild 6

Normal 2

E - 75\% 10 fish terminal kill

Gills: Hypercellularity and fusion of secondary lamellae Mild 7

Moderate 1

Norma 12 


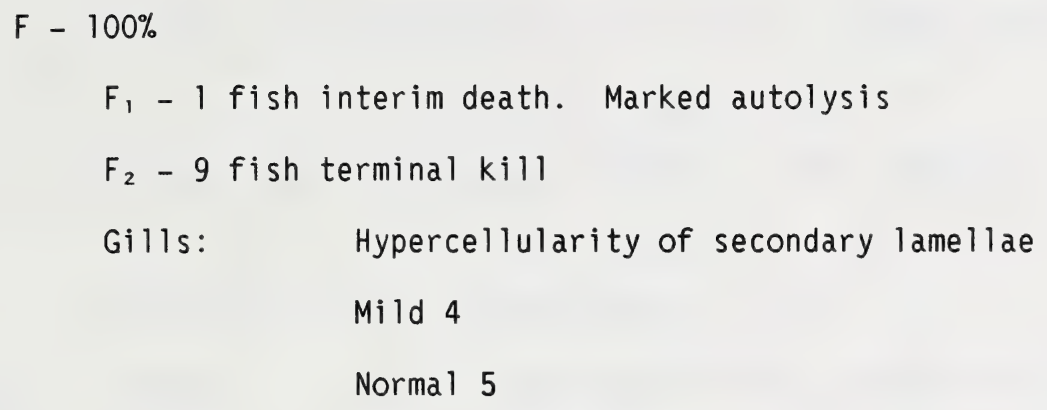

Rossdale plant \#2 (first collection)

Accession \#1788-84

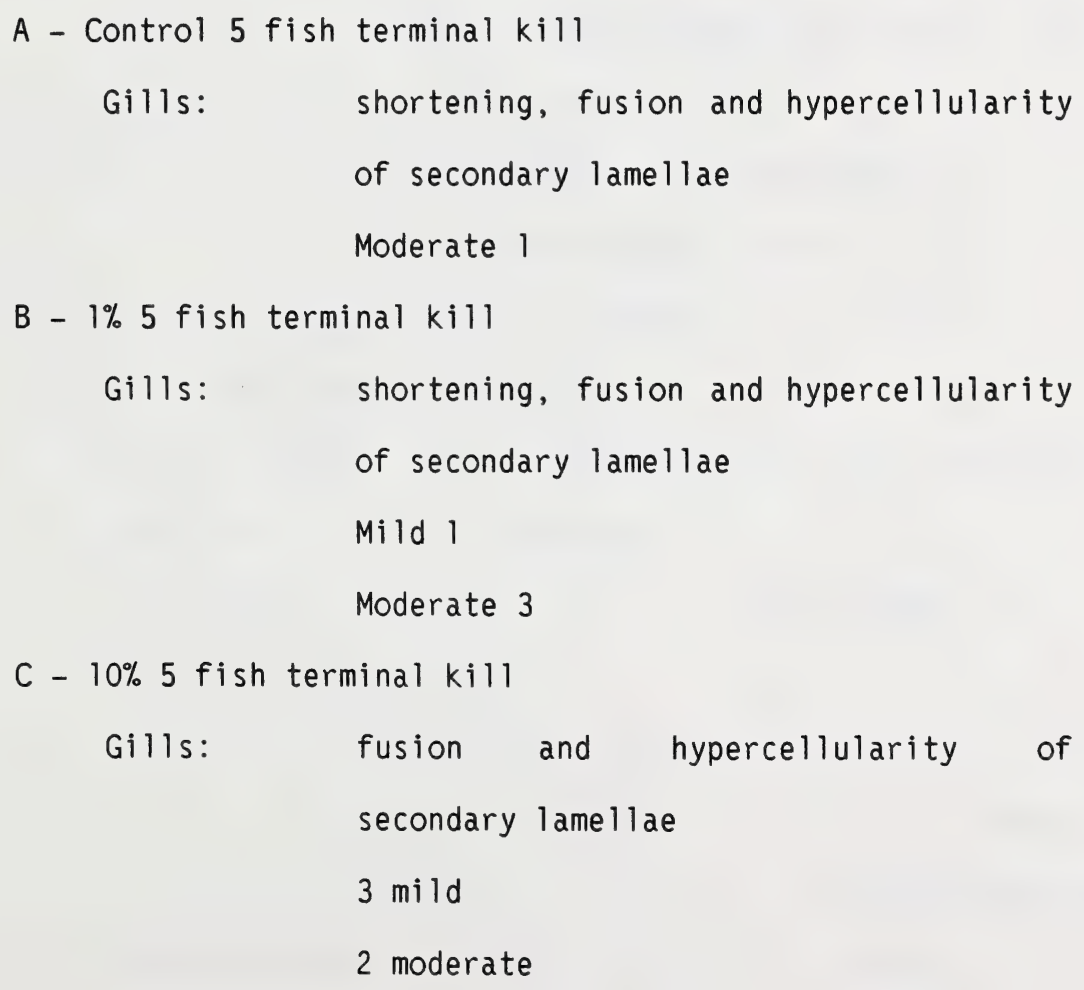


D $-50 \%$

$D_{1}-5$ fish interim death

Tissues were markedly autolyzed and unsuitable for histopathological examination.

$D_{2}-2$ fish terminal kill

Gills: Shortening and fusion with
hypercellularity of the secondary
lamellae
Mild 2

$E-75 \%$

$E_{1}-E_{3}-3$ fish interim death

Tissues were markedly autolyzed and unsuitable for histopathological examination.

$E_{3}-2$ fish terminal kill

Gills: fusion and hypercellularity of secondary lamellae

1 Mild

1 Moderate

F - $100 \%$ net run

E.L. Smith

Accession \#1836-84

A - Control 
Gills: Hypercellularity, fusion and shortening of secondary lamellae.

Mild 3

Normal 2

B - $1 \%-5$ fish terminal kill

Gills: fusion, hypercellularity and shortening of secondary lamellae

Mild 3

Moderate 2

C- 10\%-5 fish terminal kill

Gills: fusion and hypercellularity of secondary lamellae

Mild 0

Moderate 4

Marked 1

D - 50\%-5 fish terminal kill

Gills: Fusion and hypercellularity of secondary lamellae

Mild 1

E - 75\%-5 fish terminal kill

Gills: hypercellularity and fusion of the secondary lamellae

Mild 3

F - 100\%-5 fish terminal kill 
Gills: Hypercellularity and fusion of secondary lamellae

Mild 2

E.L. Smith $C_{2}$

Accession \#1943-84

A - Control - 5 fish terminal kill

Gills: fusion and hypercellularity of secondary lamellae

- Mild 3

B - $1 \% \quad 5$ fish terminal kill

Gills: hypercellularity and fusion of the secondary lamellae

$3 \mathrm{Mild}$

1 Moderate

C - $10 \% \quad 5$ fish terminal kill

Gills: hypercellularity and fusion of secondary lamellae

Mild 2

Moderate 1

D - $50 \% 5$ fish terminal kill

Gills: hypercellularity and fusion of secondary lamellae

Mild 4 
$E-75 \%$

$E_{1}$ - 1 fish interim death

Marked autolysis, unsuitable for histopathological examination

$E_{2}-E_{3}-5$ fish terminal kill

Gills: hypercellularity and fusion of

secondary lamellae

Mild - 3

Moderate 1

F - 100\% 5 fish terminal kill

No significant lesion was seen.

Glenmore

Accession \#1964-84

A - Control 5 fish terminal kill

Gills: hypercellularity, fusion and shortening of secondary lamellae

Mild 3

Moderate 1

B $-1 \%$

$B_{1}-1$ fish interim death

Moderate autolysis, unsuitable for histopathology 


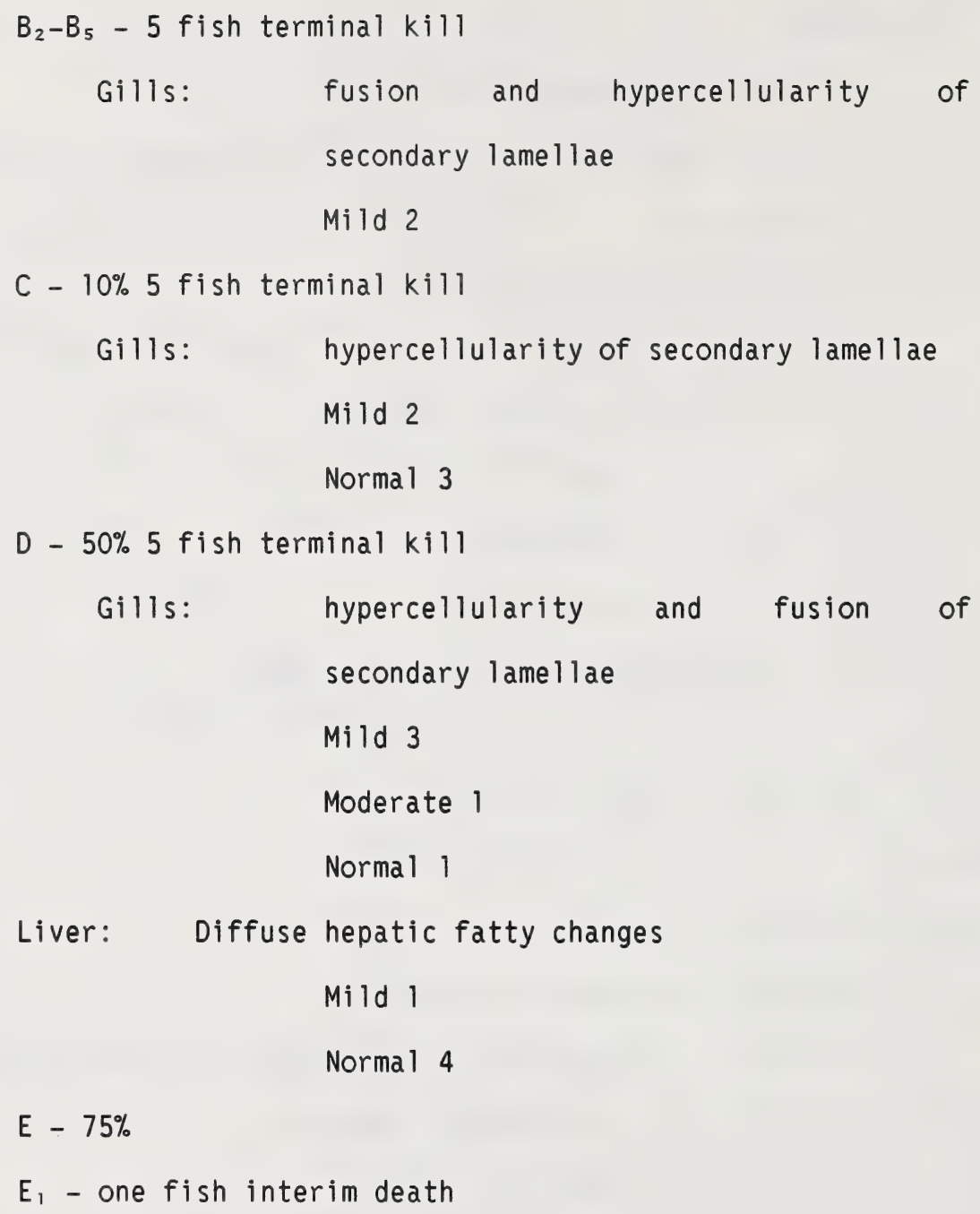

Skin: Marked diffuse erosion and sloughing of the epidermal epithelium

Large amount of yellowish brown polarized crystalline and granular material were deposited on the skin and between gill arches. 


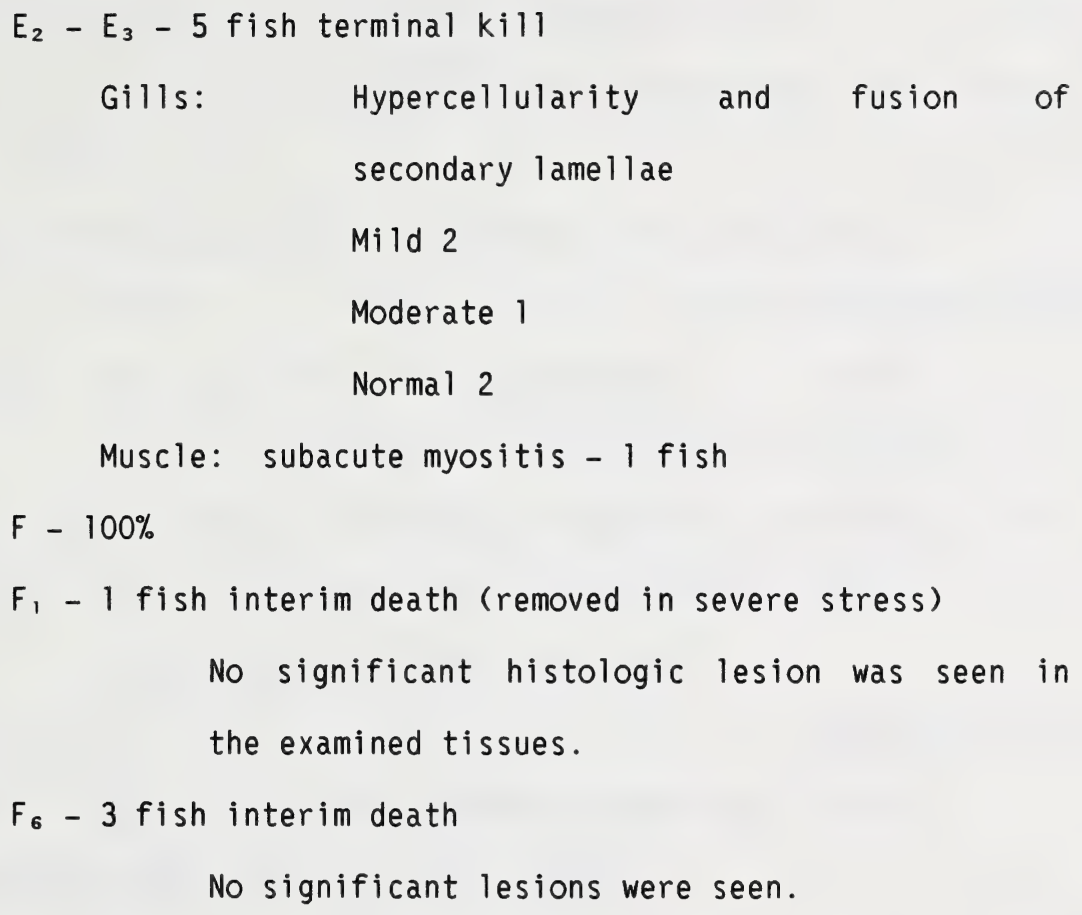


Appendix II. Histopathological findings in large fish (subacute study).

Control 1. First period $96 \mathrm{~h}$ in treated municipal water Accession \#2304-84

Gills: Mild focal hypercellularity and fusion of secondary lamellae.

Heart: $\quad$ Subacute multifocal necrotic myocarditis No other significant histologic lesion was seen in the examined tissues.

Accession \#2305-84

Gills: Mild diffuse thickening of the secondary lamellae. The thickening was due to replacement of pavement squamous epithelial cells with cuboidal ones.

Heart: Subacute focal necrotic myocarditis No other significant histologic lesion was seen in the examined tissues.

Accession \#2306-84

Stomach: Subacute perineuritis. The lesions were concentrated around nerve fibers and characterized by moderate lymphocytic infiltration and fibrosis. No other significant histologic lesion was seen in the examined tissues. 
Accession \#2307-84

No significant histologic lesion was seen in the examined tissues.

Accession \#2308-84

Gills: Mild diffuse hypercellularity of secondary lamellae

Heart: $\quad$ Subacute focal necrotic myocarditis No other significant histologic lesion was seen in the examined tissues.

Control I. Second period $96 \mathrm{~h}$ in treated municipal water Accession \#2309-84

Gills: Mild diffuse hypercellularity of the secondary lamellae.

No other significant histologic lesion

was seen in the examined tissues.

Accession \#2310-84

Heart: Chronic focal lymphocytic myocarditis

Stomach: Chronic neuritis

No other significant histologic lesion

was seen in the examined tissues.

Accession \#2311-84

Heart: Subacute focal necrotic myocarditis

No brain was examined 
No other significant histologic lesion was seen in the examined tissues.

Accession \#2312-84

Gills: Mild diffuse hypercellularity of the secondary lamellae.

No heart or pyloric ceca were examined.

No other significant histologic lesion was seen in the examined tissue.

Accession \#2313-84

Heart: $\quad$ Chronic lymphocytic myocarditis.

No other significant histologic lesion

was seen in the examined tissues.

Control 2. First period. $96 \mathrm{~h}$ in treated municipal water

Accession \#2351-84

No significant histologic lesion was seen in the examined tissues.

Accession \#2352-84

Gills: Mild diffuse hypercellularity and shortening of secondary lamellae. No other significant histologic lesion was seen in the examined tissues. 
Accession \#2353-84
Liver:
Mild hepatic fatty changes
No other significant histologic lesion
was seen in the examined tissues.

Accession \#2354-84
Gills: Mild hypercellularity of the secondary lamellae.

Stomach: Mild subacute gastritis

Control 2. Second period $96 \mathrm{~h}$ in treated municipal water

Accession \#2355-84

No significant histologic lesion was seen in the examined tissues.

Accession: $2356-84$

No significant histologic lesion was seen in the examined tissues.

Accession \#2357-84

\begin{tabular}{|c|c|c|c|}
\hline \multicolumn{4}{|c|}{ focal hypercellularity } \\
\hline & fusion of & secondar & lamellae. \\
\hline & lesions & were & associated \\
\hline
\end{tabular}


Heart: $\quad$ Subacute focal necrotic myocarditis. No stomach was examined.

Accession \#2358-84

Gills: Mild hypercellularity and shortening of the secondary lamellae.

No other significant histologic lesion was seen in the examined tissues.

Accession \#2359-84

Liver: Mild hepatic fatty changes.

Intestine: Multifocal serositis.

No other significant histologic lesion was seen in the examined tissues.

Rossdale Plant \#1

First period - Exposure to alum sludge $96 \mathrm{~h}$

Accession \#1869-84

Gills: Mild hypercellularity and shortening of the secondary lamellae. No other significant histologic lesion was seen in the examined tissues.

Accession \#1870-84

Gills: Mild diffuse hypercellularity of the secondary lamellae. 
Liver: Moderate diffuse hepatic fatty changes. No other significant histologic lesion was seen in the examined tissues.

Accession \#1871-84

Gills: Mild focal hypercellularity of the secondary lamellae.

No other significant histologic lesion was seen in the examined tissues.

Accession \#1872-84

No significant histologic lesion was seen in the examined tissues.

Accession \#1873-84

No significant histologic lesion was seen in the examined tissues.

Rossdale Plant \#1 Second period $96 \mathrm{~h}$ in treated municipal water

Accession \#1874-84

Gills: Mild diffuse hypercellularity of the secondary lamellae.

Heart: Moderate diffuse pericarditis

Stomach: Diffuse chronic gastritis

No other significant histologic lesion was seen in the examined tissues. 
Accession \# 1875-84

Gills: Mild focal hypercellularity of the secondary lamellae.

No other significant histologic lesion

was seen in the examined tissues.

Accession \# 1876-84

No significant histologic lesion was seen in the examined tissues.

Accession \#1877-84

Gills: $\quad$ Moderate focal hypercellularity and shortening of the secondary lamellae.

No other significant histologic lesion

was seen in the examined tissues.

Accession \#1878-84

Skin:

Moderate focal necrosis and vacuolation of the epidermal epithelium.

No other significant histologic lesion was seen in the examined tissues.

E.L. Smith Plant $C_{1}$ First period. Exposure for $96 \mathrm{~h}$.

Accession \#1988-84

Gills: Moderate hypercellularity, fusion and shortening of secondary lamellae. 


Multiple large cysts filled with
myxosporidia were seen in markedly
dilated blood vessels.
Heart: $\quad$ Subacute multifocal necrotic
myocarditis.
No other significant histologic lesion
was seen in the examined tissues.

Accession \#1989-84

The fish was sluggish when taken out of the water.

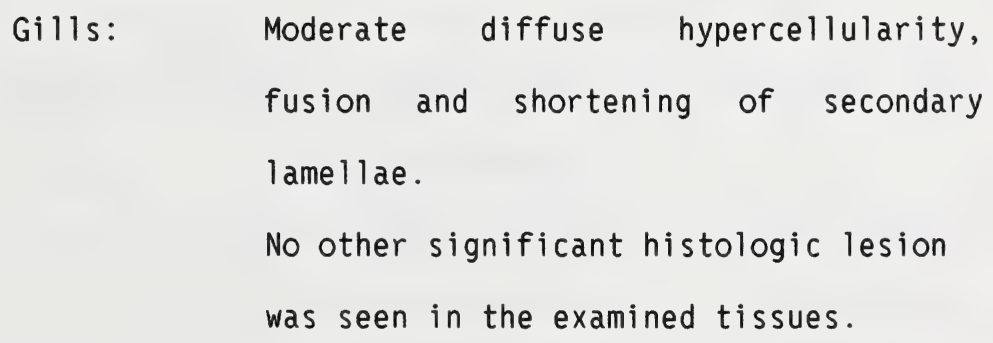

Accession \#1990-84

The fish was sluggish when taken out of the water.

$\begin{array}{ll}\text { Gills: } & \text { Moderate focal shortening, } \\ \text { hypercellularity and fusion of } \\ \text { secondary lamellae. } \\ \text { Mild focal lymphocytic pericarditis. } \\ \text { No other significant histologic lesion } \\ \text { was seen in the examined tissues. }\end{array}$

Accession \#1991-84

The fish was sluggish when taken out of the water. 


$\begin{array}{ll}\text { Gills: } & \text { Moderate focal shortening, } \\ & \text { hypercellularity and fusion of } \\ & \text { secondary lamellae. Multiple vascular } \\ & \text { thrombosis with marked dilatation. } \\ \text { Heart: } & \text { focal lymphocytic pericarditis. } \\ & \text { No other significant histologic lesion } \\ & \text { was seen in the examined tissues. }\end{array}$

Accession \#1992-84

Skin lesion on the nose was seen grossly.

Nose: Acute focal dermatitis and chondritis.

Gills: mild diffuse hypercellularity of the secondary lamellae.

No other significant histologic lesion was seen in the examined tissues.

E.L. Smith Plant $C_{1}$ Second period. $96 \mathrm{~h}$ in regular treated water.

Accession \#1993-84

No significant lesion.

Accession \#1994-84

Gills: Mild diffuse hypercellularity of the secondary lamellae. 


$$
\begin{aligned}
& \text { Heart: } \quad \text { Subacute multifocal necrotic } \\
& \text { myocarditis. } \\
& \text { No other significant histologic lesion } \\
& \text { was seen in the examined tissues. }
\end{aligned}
$$

Accession \# 1995-84

Gross Findings:

Left pectoral fin was short.

No significant histopathologic lesion

was seen in the examined tissues.

Accession \# 1996-84

Gills: Mild focal hypercellularity of the secondary lamellae.

No other significant histopathologic lesion was seen in the examined tissues.

Accession \#1997-84

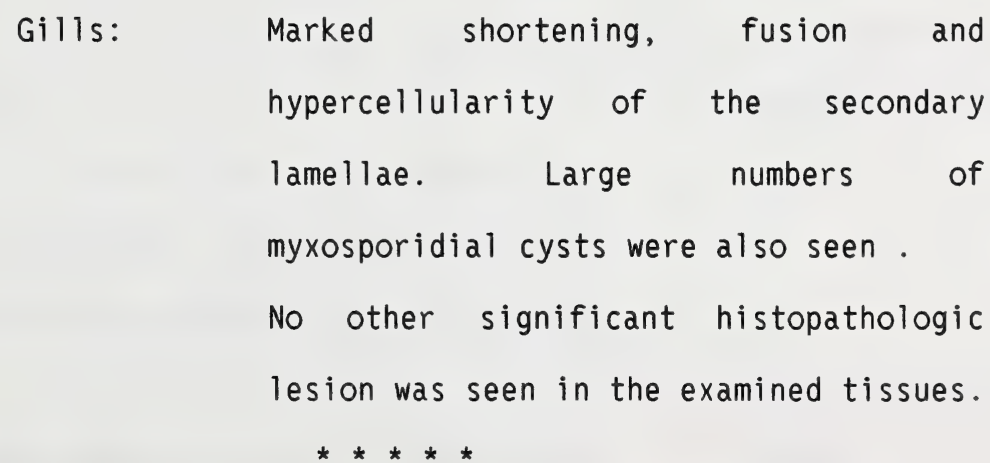


E.L. Smith $\mathrm{C}_{2}$ First period. Exposure for $96 \mathrm{~h}$

Accession \#2341-84

Gills: Mild hypercellularity and shortening of the secondary lamellae.

No other significant histologic lesion was seen in the examined tissues.

Accession \#2342-84

Gills: Mild hypercellularity of the secondary lamellae.

Liver: Moderate diffuse hepatic fatty changes. No other significant histologic lesion was seen in the examined tissues.

Accession \#2343-84

No significant histologic lesion was seen in the examined tissues.

Accession \#2344-84

Heart: Mild lymphocytic pericarditis No other significant histologic lesion was seen in the examined tissues.

Accession \#2345-84

Gills: Mild hypercellularity of the secondary lamellae.

No other significant histologic lesion was seen in the examined tissues. 
E.L. Smith $C_{2}$ second period $96 \mathrm{~h}$ in treated municipal water Accession \#2346-84

Gills: Moderate hypercellularity, fusion and shortening of the secondary lamellae.

Stomach: Diffuse subacute gastritis

No other significant histologic lesion

was seen in the examined tissues.

Accession \#2347-84

No significant histologic lesion was seen in the examined tissues .

Accession \#2348-84

Stomach: Chronic diffuse gastritis. No other significant histologic lesion was seen in the examined tissues.

Accession \#2349-84

No significant histologic lesion was seen in the examined tissues.

Glenmore Plant. First period. Exposure for $96 \mathrm{~h}$.

Accession \#2314-84

The fish was sluggish when taken out of the water.

Gills: Moderate diffuse hypercellularity and shortening of the secondary lamellae. 
No other significant histologic lesion was seen in the examined tissues.

Accession \#2315-84

The fish was sluggish when taken out of the water

The right posterior fin was ragged.

Gills: Mild focal hypercellularity and fusion of secondary lamellae.

Fin: Chronic proliferation dermatitis. No other significant histologic lesion was seen in the examined tissues.

Accession \#2316-84

Gills: $\quad$ Moderate hypercellularity and fusion of the secondary lamellae.

No other significant histologic lesion was seen in the examined tissues.

Accession \#2317-84

The fish was sluggish when taken out of the water

Gills: $\quad$ Moderate hypercellularity and fusion of the secondary lamellae.

No other significant histologic lesion was seen in the examined tissues.

Accession \#2318-84

Gills: $\quad$ Moderate hypercellularity and fusion of the secondary lamellae.

Heart: $\quad$ Chronic focal lymphocytic myocarditis 
Liver: $\quad$ Mild diffuse hepatic fatty changes. No other significant histologic lesion was seen in the examined tissues.

Glenmore plant. Second period. $96 \mathrm{~h}$ in treated municipal water.

Accession \#2319-84

Gills: $\quad$ Moderate hypercellularity and fusion of the secondary lamellae. No other significant histologic lesion was seen in the examined tissues.

Accession \#2320-84

No significant histologic lesion was seen in the examined tissues.

Accession \#2321-84

Gills: Mild focal hypercellularity of the secondary lamellae

Heart: $\quad$ Subacute focal necrotic myocarditis. No other significant histologic lesion was seen in the examined tissues.

Accession 2322-84

Gills: Mild diffuse hypercellularity and shortening of the secondary lamellae. No other significant histologic lesion was seen in the examined tissues. 
Accession \#2323-84

No significant histologic lesion was seen in the examined tissues. 


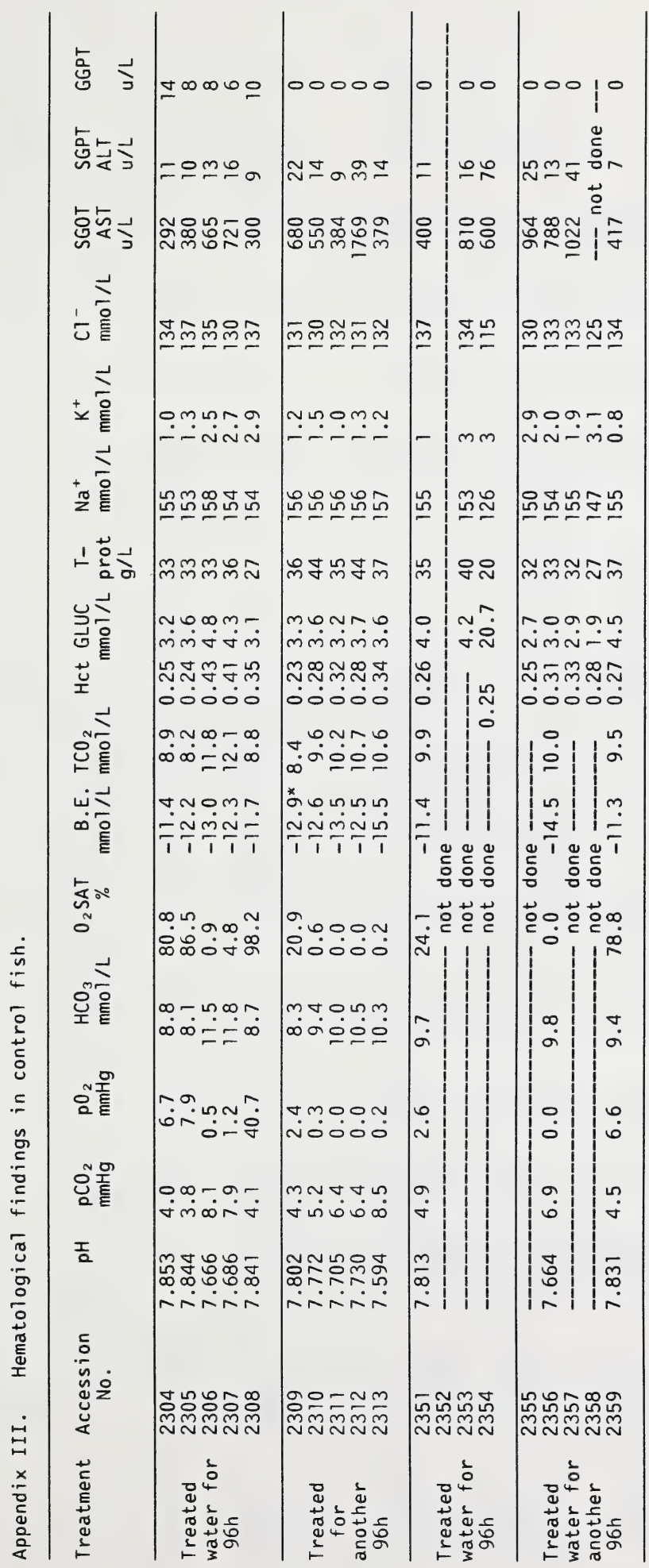




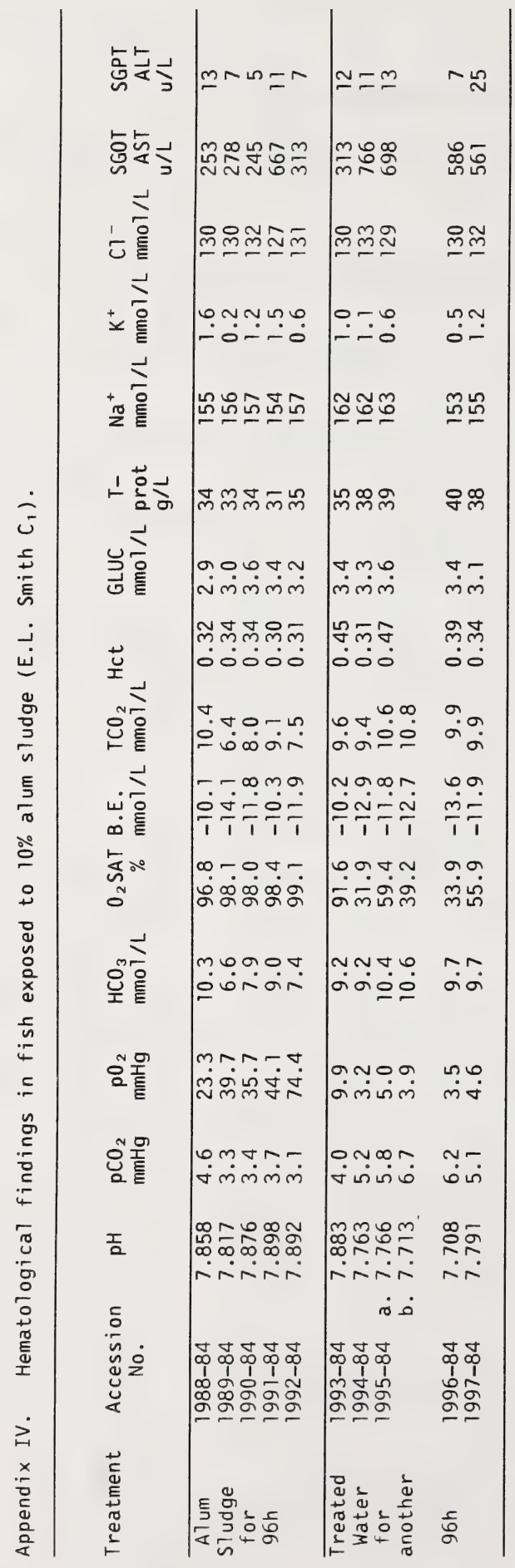




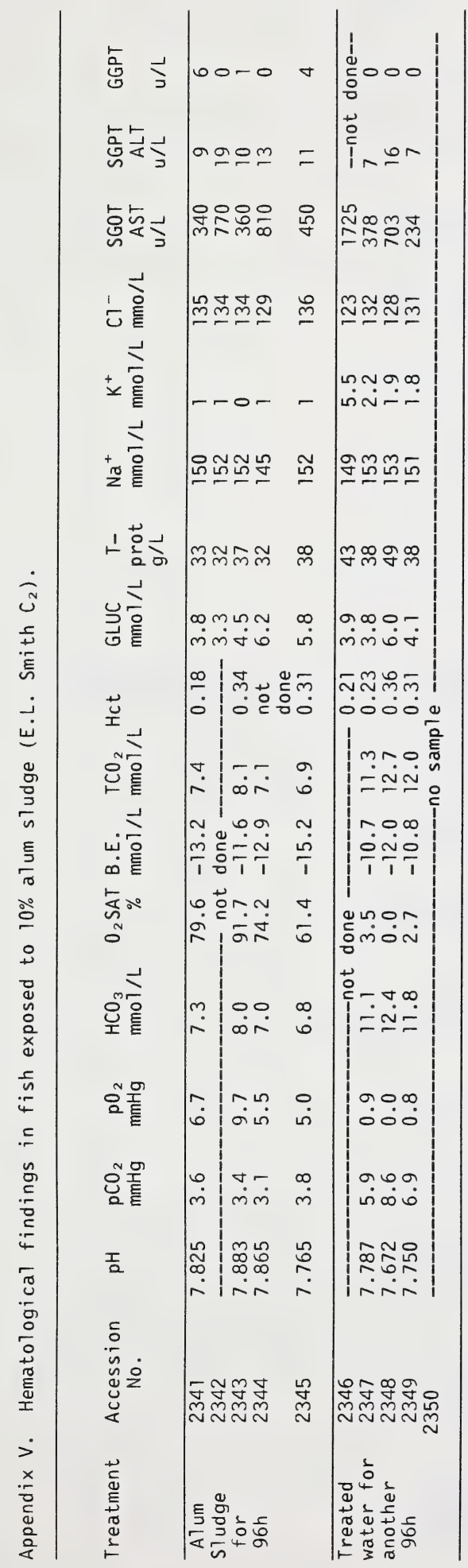




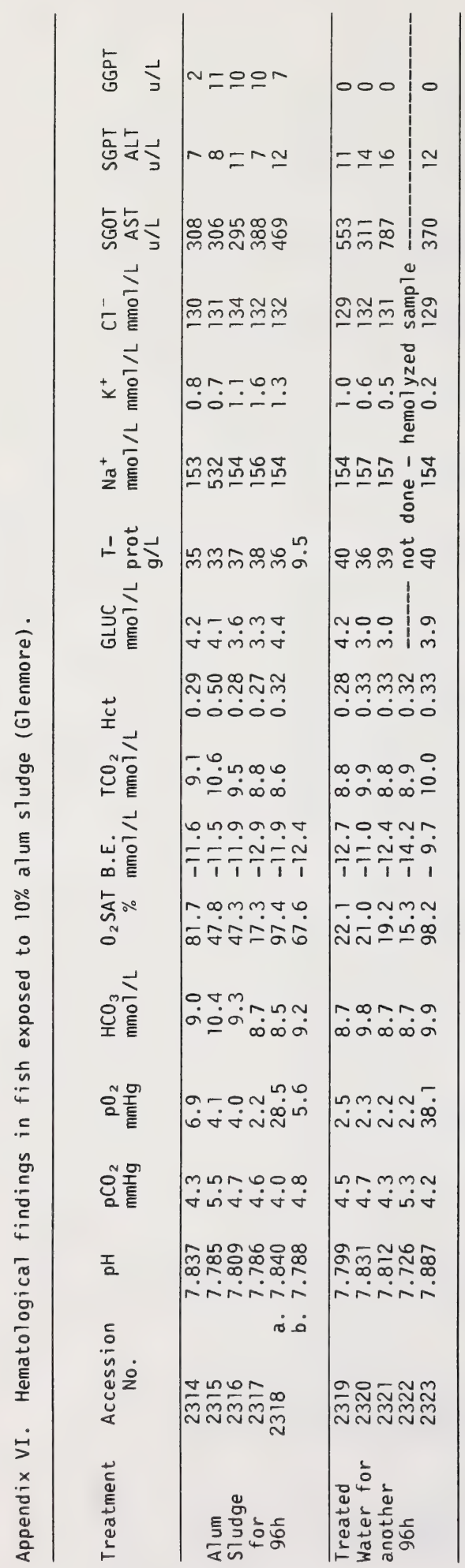


$(100)$

PART IV

RANGE FINDINGS FOR ALUM SLUDGE TOXICITY IN RATS

by

A. LOPEZ AND S. YONG 

SUMMARY

Alum sludge collected from the E.L. Smith (Edmonton), Rossdale (Edmonton) and Glenmore (Calgary) water treatment was tested for acute toxic effects using 30 seven-week-old Long Evans rats. Subgroups of two rats (male and female) were dosed by gavage administration either one, two or three times with $3 \mathrm{ml}$ of undiluted sludge. After a 14-day observation period, tissues were taken for histopathological evaluation. No mortality or clinical signs of toxicity were detected during the observation period and body weights (by sex) at the end of the study were similar among different treatment groups. Histopathological evaluation did not reveal any evidence of toxicity associated with alum sludge. Four odd lesions observed in four different rats were regarded as incidental findings unrelated to treatment. It was concluded that the alum sludge obtained from the Edmonton and Calgary water treatment plants was not acutely toxic for the rats under the dosage and conditions in which the study was conducted. 


\section{INTRODUCTION}

Range finding studies in laboratory animals are reliable and useful methods for screening and evaluating the potential toxic effects of environmental chemicals. Alum sludge originating from water treatment is generally believed to be innocuous based on its chemical composition. Nonetheless, there has been some public concern about the possible adverse effect of the sludge on the environment. The objective of this investigation was to conduct a preliminary acute toxicity test in rats dosed with alum sludges collected from four different water treatment plants in Alberta. The study was completed in two stages. The first stage was conducted between 2 and 26 of October and the test article was alum sludge collected from E.L. Smith water treatment plant in Edmonton (C2) and from Glendale plant in Calgary. The second stage was conducted from October 24 to November

21 and sludges were collected from Rossdale, E.L. Smith (CI) and E.L. Smith (C2) plants, all three from Edmonton.

\section{MATERIALS AND METHODS}

\subsection{Animals}

Seven-week-old Long Evans rats were used in this study. Animals were obtained from Charles River Canada Inc. They were housed individually in stainless steel mesh-bottomed cages. Water and 
certified commercial rodent chow were provided ad libitum. The temperature of the animals' room was maintained at $22 \pm 2{ }^{\circ} \mathrm{C}$ and the humidity at $50 \pm 30 \%$. The photoperiod in the room was set at 12 hours light and 12 hours dark.

\subsection{Dosing Regime}

Samples of alum sludges were obtained from E.L. Smith (Edmonton), Rossdale \#1 (Edmonton) and Glenmore (Calgary) water treatment plants. Three separate samples were collected from E.L. Smith plant and were identified as follows: E.L. Smith-1, collected from the clarifier 2; E.L. Smith-2 collected from clarifier 1 and E.L. Smith-3 from clarifier 2. All samples were kept refrigerated until dosing day. Thirty male and female Long Evans rats were divided into fifteen groups of one male and one female each. Each group was administered 3 $\mathrm{ml}$ of undiluted alum sludge in single, double and triple doses of each sample at 24 hours apart (Table 1).

\subsection{Clinical Observations}

Rats were observed daily for 14 days (after the last dosing) for clinical signs and mortality. Rats dosed with alum sludge from E.L. Smith-1, E.L. Smith-3 and Rossdale plants were weighed four times during this period. 


\subsection{Histopathology}

A complete necropsy was carried out on each rat at the end of the experiment. Pieces of different tissues and organs were fixed in $10 \%$ buffered formalin. Tissue sections of 5-6 $\mu \mathrm{m}$ in thickness were prepared and stained with hematoxylin and eosin. The following tissues were examined: brain, liver, spleen, thymus, pancreas, adrenal glands, salivary glands, maxilary lymph node, lungs, stomach, intestine, muscle gonads, kidneys, tongue, trachea, thyroid, heart, spinal cord, sciatic nerve, pituitary gland and femoral bone.

\section{RESULTS AND DISCUSSION}

\subsection{Clinical Observations}

No mortality or clinical signs were seen in any rats except one rat which had focal areas of alopecia around the shoulder. This rat had received one dose only and the lesion was interpreted as incidental.

The growth rate of rats was not affected by the sludge and gain in growth was steady. Table 2 gives the individual body weight and gain during the study period. 


\subsection{His topathology}

No significant gross or histopathologic lesion was seen in any rat. Histopathologic lesions were seen in some rats. These lesions were mild periportal hepatic vacuolation (one rat), severe chronic lymphocytic prostatitis (one rat), mild and localized granulomatous pneumonia confined to a single pulmonary lobe (Table 3 ). Another two rats had a few inflammatory cells within the lumen of the uterus and this was explained as a normal physiological response to ovulation. Similarly, seven female rats had discrete nuclear changes (pyknosis and karyorrhexis) in cells of the corpus luteum (Table 3).

None of the histologic lesions could be associated with the oral administration of alum sludges and were regarded as incidental findings. Lymphocytic prostatitis and vacuolation of hepatocytes are incidental findings of unknown cause. The single granuloma observed in the lung of one rat was of no clinical significance and perhaps resulted from aspirated sludge during gavage manipulation. Inflammatory cells in the uterine lumen and pyknotic nuclei in corpus luteum are considered normal physiologic changes observed during the estrus cycle of rats.

The lack of clinical signs and lesions indicate that the alum sludges from E.L. Smith, Rossdale and Glenmore plants were not acutely toxic under the conditions of the present range finding study. Based on these results, further tests for acute toxicity in rats were not warranted. 
Table 1. Number of gavages per rat and animal numbers.
Alum sludge
Study Gavage/rat
Rat Number

Male

Female

E.L. Smith

E.L. Smith

E.L. Smith

Glenmore

Glenmore

Glenmore

E.L. Smith

E.L. Smith

E.L. Smith

E.L. Smith

E.L. Smith

E.L. Smith

$\begin{array}{ll}1 & 1 \\ 1 & 2 \\ 1 & 3\end{array}$

1743

1737

$2 \quad 1742$

1748

1741

1747

$\begin{array}{ll}1 & 1 \\ 1 & 2 \\ 1 & 1\end{array}$

1738

1744

1740

1746

1745

2
2
2

1906

1916

$2 \quad 1907$

1922

1912

1919

Rossdale

Rossdale

2

1911

1923

1909

1923

23

1913

1920

Rossdale

$\begin{array}{ll}2 & 1 \\ 2 & 2 \\ 2 & 3\end{array}$

1910

1918

1908

1917

1915

1921 
Table 2 Individual Body Weights (grams) for rats treated with Alum Sludges from Rossdale, E.L. Smith-1, and E.L. Smith-3, Edmonton .

\begin{tabular}{|c|c|c|c|c|c|}
\hline \multicolumn{6}{|l|}{ Rossdale-Edmonton } \\
\hline \multirow[t]{2}{*}{$\begin{array}{ll}\text { Dates } & M\end{array}$} & \multicolumn{2}{|l|}{3 doses } & \multicolumn{2}{|l|}{2 doses } & \multirow[t]{2}{*}{$\begin{array}{l}1 \text { dose } \\
F\end{array}$} \\
\hline & & M & & M & \\
\hline Nov. 6 & 186 & 243 & 207 & 242 & 185 \\
\hline Nov. 8 & 185 & 254 & 221 & 254 & 196 \\
\hline Nov. 13 & 198 & 289 & 241 & 280 & 205 \\
\hline Nov. $20 \quad 311$ & 217 & 326 & 270 & 309 & 222 \\
\hline \multicolumn{6}{|l|}{ Body wt. change } \\
\hline Nov.6-Nov. $20 \quad 67$ & 31 & 83 & 63 & 67 & 37 \\
\hline \multicolumn{6}{|c|}{ E.L. SMITH-1 - Edmonton } \\
\hline Nov. $6 \quad 225$ & 184 & 235 & 175 & 250 & 198 \\
\hline Nov. 8 & 195 & 252 & 183 & 268 & 204 \\
\hline Nov. 13 & 206 & 275 & 196 & 296 & 222 \\
\hline Nov. $20 \quad 309$ & 220 & 306 & 195 & 328 & 239 \\
\hline \multicolumn{6}{|l|}{ Body wt. change } \\
\hline Nov. $6-20 \quad 84$ & 36 & 71 & 20 & 78 & 41 \\
\hline \multicolumn{6}{|c|}{ E.L. Smith-2 - Edmonton } \\
\hline Nov. $6 \quad 251$ & 184 & 245 & 181 & 212 & 186 \\
\hline Nov. 8 & 195 & 261 & 188 & 226 & 186 \\
\hline Nov. 13 & 207 & 292 & 199 & 253 & 201 \\
\hline Nov. $20 \quad 339$ & 224 & 317 & 208 & 280 & 206 \\
\hline \multicolumn{6}{|l|}{ Body wt. change } \\
\hline Nov.6-Nov. $20 \quad 88$ & 40 & 72 & 27 & 68 & 20 \\
\hline
\end{tabular}


Table 3. Histopathological findings.

\begin{tabular}{lll} 
Rat No. & Alum Sludge & \multicolumn{1}{c}{ Lesion } \\
\hline 1738 & Glenmore & Mild periportal hepatic vacuolation \\
1915 & Rossdale & Chronic lymphocytic prostatitis \\
1917 & Rossdale & Focal granulomatous pneumonia \\
1921 & Rossdale & Leukocytes in uterine lumen \\
1923 & E.L. Smith & Leukocytes in uterine lumen
\end{tabular}


(109)

PART V

MICROBIOLOGICAL STUDIES

by

ANSAR QURESHI

MICROBIOLOGY GROUP

CHEMISTRY WING 

SUMMARY

(1) In general, the densities of total coliforms, fecal coliforms and fecal Streptococci ranged from $1.3 \times 10^{4}$ to $4.0 \times 10^{5}$ per 100 $\mathrm{mL}$ with Rossdale plant samples. The concentrations of heterotrophic bacteria were also high $\left(2.2 \times 10^{6}\right.$ to $1.5 \times$ $10^{7} / \mathrm{mL}$ ) in these samples. The levels of both groups of bacteria, however, were comparatively low in the first set of samples from the E.L. Smith plant, as well as in the second set of samples from both plants.

(2) Regarding the microbial toxicity testing, all samples were found to be non-toxic by the Microtox tests.

(3) Based on the insufficient microbiological data, it is difficult to evaluate the potential environmental impact of alum sludge discharges. Additional work, therefore, is required to provide such information and for improved assessment and microbiological characterization of alum sludge discharges. 


\section{INTRODUCTION:}

The objectives of the microbiological studies were: (i) to determine the incidence and levels of pollution indicator and heterotrophic bacteria in alum sludge for microbiological characterization, ( $i i)$ to evaluate the relative toxicity of alum sludge using microbial systems, and (iii) to evaluate the potential environmental impact of alum sludge discharges using all microbiological data.

\section{METHODS}

\subsection{Microbiological Analyses}

All alum sludge samples were analyzed for levels of Total Coliform (TC), Fecal Coliform (FC) and Fecal Streptococcus (FS) bacteria according to the APHA Standard Methods for the Examination of Water and Wastewaters, 15th ed. (1) using the membrane filter technique. Membranes used were Millipore, pre-sterilized, $47 \mathrm{~mm}$ diameter, $0.45 \mu \mathrm{m}(0.7 \mu \mathrm{m}$ for $F C)$, and white gridded filters. Densities of heterotrophic bacteria (Plate Count) were determined using the spread plate technique following the procedure outlined in the draft for the APHA Standard Methods, 16th ed. (2). 


\subsubsection{Total Coliform (TC)}

TC densities were determined on m-Endo agar LES after incubation at $35 \pm 0.5^{\circ} \mathrm{C}$ for 22 to $24 \mathrm{~h}$. Duplicate membrane filtrations were made for three appropriate volumes (dilutions) of each sample, and the presence of typical pink to dark-red colonies with a metallic (green-gold) surface sheen was considered as evidence of the presence of total coliforms. Colony counts were made from the most appropriate dilution and recorded as TC per $100 \mathrm{~mL}$ original sample.

\subsubsection{Fecal Coliform (FC)}

FC were enumerated on $\mathrm{m}-\mathrm{Fc}$ agar following incubation at $44.5^{\circ} \mathrm{C} \pm 0.5^{\circ} \mathrm{C}$ after $24 \pm 2 \mathrm{~h}$. Duplicate membrane filtrations were made for three appropriate sample volumes (dilutions), and all blue (various shades) colonies were counted as fecal coliforms. Densities were expressed as FC per $100 \mathrm{~mL}$ sample.

\subsubsection{Fecal Streptococcus (FS)}

FS levels were determined on KF Streptococcus agar with incubation at $35 \pm 0.5^{\circ} \mathrm{C}$ for $48 \mathrm{~h}$. Duplicate membrane filters were made for three appropriate sample volumes (dilutions), and all pink to dark-red (maroon) colonies were counted as fecal streptococci. Counts were recorded as FS per $100 \mathrm{~mL}$ sample. 


\subsubsection{Heterotrophic Plate Count (HPC)}

Heterotrophic bacteria were enumerated on Plate Count agar after incubation at $20 \pm 0.5^{\circ} \mathrm{C}$ for $48 \mathrm{~h}$ and $35 \pm 0.5^{\circ} \mathrm{C}$ for 96 h. Aliquots of $0.1 \mathrm{~mL}$ sample/appropriate sample dilutions were pipetted onto the surface of predried agar plates (plates were dried with lids off in a laminar flow hood at room temperature for $(\mathrm{h})$. Using a sterile bent glass rod, the inoculum was distributed over the entire surface of the medium by rotating the dish on an automatic turntable. Plates were maintained at room temperature $\left(22^{\circ} \mathrm{C}\right)$ for approximately $1 \mathrm{~h}$ to allow the inoculum to be absorbed completely into the medium before incubating at the designated temperatures. Four replicate plates were prepared for three appropriate sample volumes (dilutions), and all colonies from the most appropriate dilution were counted. Densities of heterotrophic bacteria were expressed as Colony Forming Units (CFU) per $\mathrm{mL}$ sample, separately for $20^{\circ} \mathrm{C}$ and $35^{\circ} \mathrm{C}$.

\subsection{Microbial Toxicity Testing}

Alum sludges were subjected to toxicity testing using several organisms from different trophic levels. Relative toxicity of alum sludges to micro-organisms was determined by the Microtox toxicity test. The test involves monitoring changes in the light production by hydrated luminescent bacteria (Photobacterium phosphoreum) in a temperature controlled $\left(15^{\circ} \mathrm{C}\right)$ photometer in the presence of varying concentrations of an effluent or toxicant. In the Microtox test, the 
effective concentration of a test sample causing $50 \%$ decrease in light output (EC50) is used as the index of relative toxicity.

All assays were performed using the Microtox Model 2055 Toxicity Analyzer (Beckman Instruments, Inc., Carlsbad, CA) according to the procedures described by the manufacturer (3) and Qureshi et. al. (4). Test samples were analyzed as $90,45,22.7,11.4,5.7$ and $2.9 \%$ original sample. Light measurements were made at 5, 10, 15, and 20 minutes after sample addition to the bacterial reagent; however, the 15-min EC50 was used as the assay end point for toxicity assessment.

\section{RESULTS AND DISCUSSION}

Interpretation of microbiological data is somewhat difficult as only seven samples were analyzed from both plants and some of these were stored for up to 20 days before testing. In general, however, the levels of all fecal pollution indicator bacteria (TC, FC, FS) and heterotrophic bacteria were relatively high in the Rossdale Plant samples. The values for TC, FC and FS ranged from $1.3 \times 10^{4}$ to 4.0 $x 10^{5} / 100 \mathrm{~mL}$, and for $\mathrm{HPC}$ (both $20^{\circ} \mathrm{C}$ and $35^{\circ} \mathrm{C}$ ) varied between $2.2 \times$ $10^{6}$ and $1.5 \times 10^{7} / \mathrm{mL}$ (Table 1). In comparison, bacterial densities of both groups were considerably lower in the first set of samples from the E.L. Smith Plant and in the second set of samples from both plants. It is also interesting to note that these samples 
were taken only at the start of the precipitation process and so contained little or no alum sludge flocs/precipitates.

Based on these preliminary results, it is suggested that representative samples of the alum sludge processes should be analyzed for better assessment of potential public health risk that might be associated with the alum sludges. A recent study (5) of the removal and inactivation of bacteria during alum treatment (for phosphorous removal) of a eutrophic recreational lake indicated that alum floc poses a potential human health hazard if ingested by swimmers or if the lake is used as a source of potable water.

Regarding the microbial toxicity testing, none of these sludge samples elicited a toxic response by the Microtox test. These results indicate that the samples, as tested, were relatively non-toxic but due to the small data base it is difficult to truly assess the potential impact (in terms of toxicity) of alum sludge discharge on the aquatic ecosystem. 
Table 1. Levels of Fecal Pollution Indicator and Heterotrophic Bacteria in Alum Sludge Samples from Two Plants.

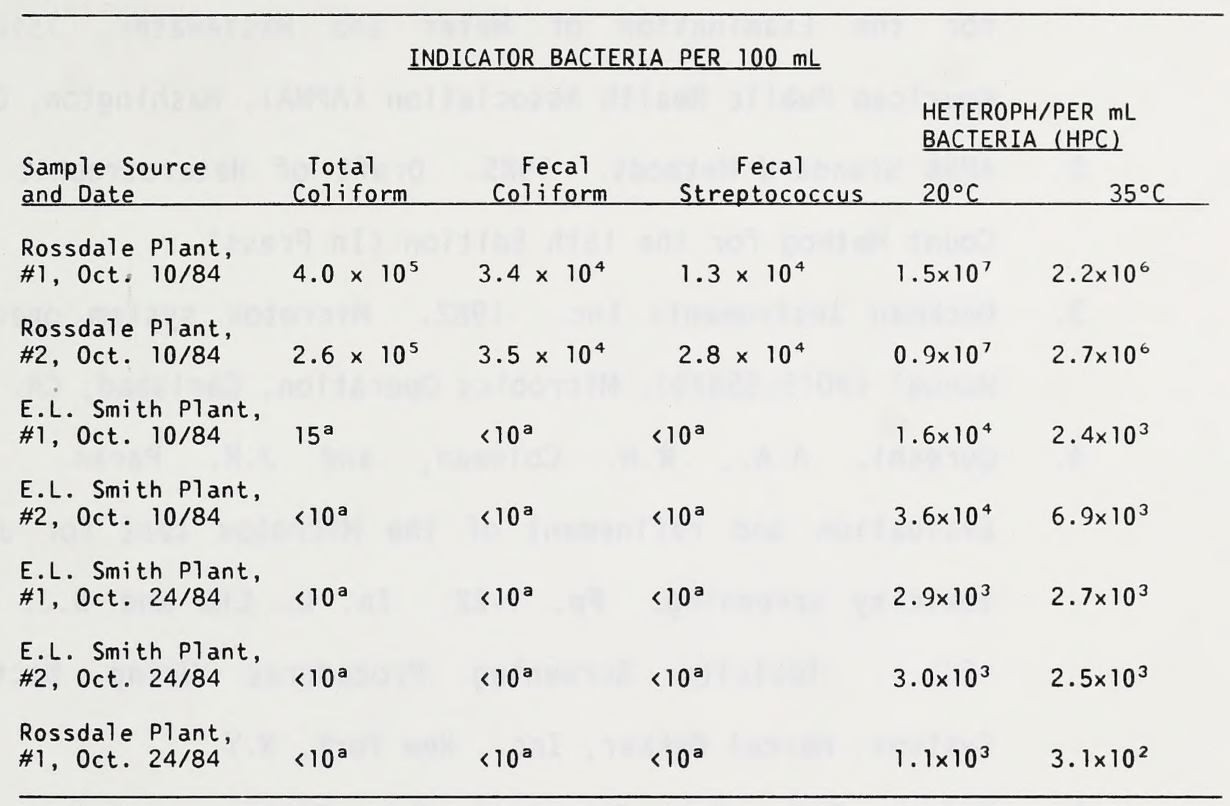

a Estimated counts based on numbers below lower $\mathrm{Cr}$ counting limit. 


\section{REFERENCES}

1. American Public Health Association. 1980. Standard Methods for the Examination of Water and Wastewater, 15th ed. American Public Health Association (APHA), Washington, D.C.

2. APHA Standard Methods. 1985. Draft of Heterotrophic Plate Count Method for the 16th Edition (In Press).

3. Beckman Instruments Inc. 1982. Microtox system operating Manual (\#015-55879), Microbics Operation, Carlsbad, CA.

4. Qureshi, A.A., R.N. Coleman, and J.H. Paran. 1984. Evaluation and refinement of the Microtox test for use in toxicity screening. Pp. 1-22. In. D. Liu and B.J. Dutka (Eds.), Toxicity Screening Procedures Using Bacterial Systems, Marcel Dekker, Inc., New York, N.Y.

5. Bulson, P.C., D.L. Johnstone, H.L. Gibbons, and W.H. Funk. 1984. Removal and inactivation of bacteria during alum treatment of a lake. , Applied Environmental Microbiology, 48(2): $425-430$. 

